\title{
A ESTRUTURA FORMAL DA ARGUMENTAÇÃO DE SÃO PAULO E AS SUAS POSSIVEIS RELAÇõES COM A LóGICA ESTÓICA
}

\author{
JORGE CESAR MOTA
}

\begin{abstract}
Aos meus caros e inesqueciveis mestres Professores Livio Teixeira e João Cruz Costa
\end{abstract}

Todos quantos se interessam pelos estudos bíblicos estão a par do fato de que um grande número de exegetas e críticos tem procurado, com maior ou menor sucesso, há pelo menos um século, demonstrar a evidência de elementos estóicos na forma, no estilo, no vocabulário e até mesmo nas idéias de alguns dos autores do Novo Testamento ${ }^{(1)}$. A discussão desse problema tão importante e tão amplo refoge, naturalmente, pelo menos em parte, aos objetivos de uma revista dedicada a questões filosóficas. Contudo, ele é aqui mencionado porque, em primeiro lugar, o tema do presente artigo é, de certo modo, aparentado com aquela questão e, depois, porque pretendo começar dizendo estranhar o

NOTA: Os números entre colchetes remetem à bibliografia, no final do artigo.

(1) [85] p. 84; [47] pp. 19ss e 194ss; [90] vol .I pp. 288ss; [89] pp. 68ss; [95] p. 175; [41] p. 36; [98] pp. 37ss; 261s; $343 \mathrm{~s} ;$ [74] pp. 63, $131 \mathrm{~s}$; Schmidt, K. L., Der Apostel Paulus und die antike Welt (Vorträge der Bibliotek Warburg), 1924-25, p. 60ss., apud [74] loc. cit.; [24] vol. I pp. 65ss; 70ss; 106ss; [22] passim; [4] p. 150; St George Stock, in Hastings Dict. of the Bible, vol. IV s/v Stoics; Lighfoot, Philippians (Excursus sobre São Paulo e Sêneca); [79] pp. 93-165, passim; [37] pp. 15-45. Ver ainda: Les Actes de Paul et ses Lettres apocryphes. Introduction, textes, traduction et commentaire par Léon Vouaux, Paris, 1913; Commentaire du Nouveau Testament: Pierre 
total silêncio dos especialistas sobre a matéria que é objeto deste estudo. É verdade que duas coisas poderiam ocorrer no caso: ou a bibliografia, aliás, não pequena, a que, por um motivo ou outro, não tive acesso é exatamente aquela na qual o assunto é discutido; ou então, o silêncio se explica pela inconsistência e desrazão da minha hipótese. A publicação deste trabalho evidencia que não estou de acordo com a segunda alternativa. Apesar das imperfeições próprias de um estudo ainda incompleto, pareceu-me conveniente publicá-lo precisamente para ter oportunidade de receber as críticas construtivas dos especialistas e dos estudiosos dos campos envolvidos, aos quais, desde já, agradeço a colaboração.

Muitos anos decorreram desde que a idéia surgiu na minha mente pela primeira vez. Seguia, então, o curso de Lógica ministrado pelo professor Gilles G. Granger, na Universidade de São Paulo. A coincidência, nas minhas leituras, do exame dos textos doxográficos dos megáricos e estóicos com o dos do apóstolo Paulo, nas suas epístolas e nos discursos que dele Lucas registrou nos Atos dos Apóstolos, despertou, no meu espírito, a viva impressão de notável semelhança entre o formalismo lógico que aquelas escolas socráticas contrapunham ao de Aristóteles e, em geral, a estrutura da argumentação do apóstolo dos gentios.

Bonnard (Philippiens), 1950; Charles Masson (Colossiens), 1949; Jean Héring (1 Corinthiens), 1949; P. M. J. Lagrange, Epitre aux Romans, Paris, 1950.

Qualquer leitor atento de Sêneca e de Epiteto descobrirá interessantes coincidências entre o pensamento desses conhecidos filósofos estóicos e do apóstolo São Paulo. Tratar-se-á de mera coincidência? A ética estóica parte do pressuposto epistemológico de que o conhecimento não consiste num simples saber teórico, que se pode reter na memória, mas antes num saber vital que impele a vontade e se encarna na vida, autên. tica e vigorosamente. A. Schmekel (Die hellenist-röm. Philosophie Grosse Denker)) assim definiu o sábio estóico: "O sábio possui um saber perfeito e, com ele, a energia para pô-lo em prática, como consequiência." Apud [111] p. 332. E interessante notar o procedimento literário de São Paulo na maneira de coordenar o conhecimento da doutrina e a vida moral do cristão na relação quase de causa e efeito. A segunda vem a ser, na realidade, de acordo com a teologia paulina, conseqüência natural da primeira. Observa-se isso claramente na própria estrutura das epístolas, nas quais o apóstolo trata, em primeiro lugar, dos fundamentos doutrinários e teológicos, para, em seguida, passar às questões de ordem ética. Note-se, por exemplo, em Romanos a forma conjuntiva causal com que o escritor faz a ligação das duas partes da carta $(R m 12,1)$. Ver também, Ef 4,1 . 
O presente estudo é, na sua modéstia, uma tentativa de resposta ao desafio do prof. Granger que, na ocasião, me estimulou a empreender a pesquisa. Apresentei-o, primeiramente, como parte de um curso monográfico sobre o estoicismo que ministrei na disciplina de História da Filosofia, sob minha responsabilidade, na Faculdade de Filosofia, Ciências e Letras de Assis.

\section{A hipótese de trabalho}

A hipótese de trabalho que proponho oferece oportunicade para a pesquisa em dois campos distintos, que se caracterizam nas seguintes proposições:

1) Existem, de fato, na linguagem retórica e epistolar de São Paulo, elementos claros e suficientes para se suspeitar da influência da lógica megárico-estóica no discurso religioso (para usar a terminologia de Boschenski) desse apóstolo.

2) Existem, além disso, circunstâncias na vida de Saulo de Tarso, anterior ao seu ingresso no ministério apostólico, que lhe poderiam ter possibilitado amplamente o conhecimento do formalismo lógico difundido pela Stôa.

3) Tivesse ou não o discípulo de Gamaliel conhecido outro instrumento formal de raciocínio, como em especial o de Aristóteles, além do método rabínico e do de Crísipo; tivesse ele, por consequência, tido ou não, oportunidade ou necessidade de escolha entre eles, optando pela forma estóica; é inquestionável o grande auxílio que lhe poderia prestar c sistema estóico no seu discurso teológico, em virtude da natureza e do conteúdo da mensagem que se propôs transmitir a um mundo então extraordinariamente influenciado pelo estoicismo, mensagem que consistia, basicamente, na interpretação da história do seu próprio povo - o povo de Israel - narrada na Sagrada Escritura, e dos acontecimentos ocorridos nos seus próprios dias em torno da vida, morte e ressurreição de Jesus Cristo, de quem ele se confessava servo e se proclamava apóstolo.

\section{Fontes}

Hans von Arnim, Stoicorum veterum fragmenta, Teubner, 1903-1905. 3 volumes. 
C. J. de Vogel, Greek philosophy, a collection of texts with notes and explanation, vol. III: The hellenistic Roman period, Leiden, 1959. 1958.

H. Diels, Doxographi Graeci, Berlin, 1879; 3. ${ }^{a}$ edição,

A. C. Pearson, The Fragments of Zeno and Cleanthes, London, 1891.

Cícero, (Séc. I A.C.)

De Fato

Paradoxa stoicorum

De natura deorum

Academica

De divinatione

Seneca (Séc. I D.C.)

Ad Lucilium epistolarum moralium

De vita beata

Naturales questiones

Epicteto (Séc. I D.C.)

Diatribai

Egxeirídion

Sextus Empiricus (Séc. III D.C.)

Pyrroneion Hypotyposeon

Pros Mathematikous

Pros Logikous

Diógenes Laércio (Séc. III D.C.)

Bíon kaì gnômon tòn'en philosophíae eudokimesánton 1973

Biblia Hebraica, edit. Rudolf Kittel, Stuttgart, 16. ${ }^{\mathrm{a}}$ ed.,

Novum Testamentum Graece et Latine, edit. E. Nestle, 16. ${ }^{\text {a }}$ edição, 1954. Stuttgart.

The Greek New Testament, Edit. Kurt Aland et all, 2. ${ }^{\mathrm{a}}$ edição, 1969, Stuttgart.

A Bíblia Sagrada, trad. João Ferreira de Almeida, Sociedade Bíblica do Brasil, Rio, 1951.

La Bible de Jerusalem, Paris, 1973. 1953.

The Holy Bible, Revised Standard Version, New York, 


\section{A lógica estóica}

O estoicismo, como se sabe, durou do século III A.C. ao século II D.C., cinco séculos, portanto, ou pouco mais, mas não permaneceu o mesmo, nas suas ênfases, no decorrer desse período. Na primeira fase (sécs. III-II A.C.), a Escola, fundada por Zenão de Citium, e mantida em alto nível por Cleanto e especialmente por Crísipo - considerado o segundo fundador da Stôa — preocupou-se principalmente com os problemas relacionados com a física, a moral e a lógica, o que não aconteceu com os períodos seguintes. O Médio (II-I A.C.), cujos principais nomes são: Posidônio e Panécio, e o Novo (nos primeiros dois séculos da nossa era), com Sêneca, Epiteto e Marco Aurélio, nos quais as questões de ordem moral constituiram a sua maior preocupação.

O período áureo da lógica estóica foi, pois, o mais antigo, cujos mestres haviam recebido e desenvolveram os trabalhos de Eubúlides, Diodoro e Filo, da Escola Megárica, incompreensivelmente logo desaparecida. O mais ilustre nome dessa primeira fase foi, sem dúvida, Crísipo (277-204 A.C.). "Se os deuses algum dia se interessassem pela lógica - diziam os seus contemporâneos - seria a de Crísipo que haviam de escolher". Desgraçadamente, de quanto escreveu esse filósofo, o mais fecundo escritor da antigüidade - a sua obra chegou a 705 livros! - tudo se perdeu, salvo umas Lógica Zetêmata (Pesquisas Lógicas) que se acharam entre papiros encontrados nas escavações de Herculanum ${ }^{(2)}$. Aos biógrafos e comentadores desse autor devemos tudo o que hoje se sabe dele. Quanto à importância das suas idéias para o nosso estudo, basta lembrar que Diógenes Laércio chegou a dizer que, sem ele, a Stôa não teria existido.

Como é nosso objetivo pesquisar a influência da lógica estóica na estrutura formal da argumentação do apóstolo Paulo, é evidente que não caberia neste artigo qualquer esforço de exposição e explicação de todo o sistema, e muito menos qualquer tentativa de desenvolver cálculos proposicionais, que seria inteiramente artificial, pelo anacronismo da experiência. Entretanto, torna-se necessário fazer breve referência aos seus rudimentos básicos e mais elementares. Parece óbvio que a esquematização especulativa, elaborada sobre esses fundamentos, que constituiram, no seu conjunto,

(2) [9] p. 83. 
um modelo precursor da lógica proposicional moderna, estava ausente dos programas escolares vigentes no Império Romano no primeiro século da nossa era, sendo reservada aos estudos superiores seguidos pelos especialistas. Os historiadores da educação sublinham, entretanto, a importância da obra pedagógica de Crísipo, considerado um dos mais geniais educadores dos tempos antigos, cuja influência se estendeu ao longo dos séculos por todo o período helenístico, sobretudo no tocante à didática da linguagem e da gramática.

Não cabe aqui, também, discutir as razões pelas quais o formalismo lógico dos estóicos prevaleceu sobre o dos peripatéticos, que só veio a recuperar o seu prestígio em plena Baixa Idade Média, praticamente a partir de Abelardo (1079-1142) .

Deixando de lado os evidentes reflexos da influência estóica até mesmo no pensamento de muitos dos primeiros padres da Igreja, é fácil respigar, aqui e ali, ao acaso, sinais da presença dos filósofos do Pórtico entre os primitivos cristãos. Ao narrar, por exemplo, o processo da sua conversão, o maior filósofo do cristianismo antigo, Justino, cognominado o Mártir, conta como foi precisamente um estóico que ele foi procurar primeiro, na sua desesperada ânsia de conhecer o caminho da verdadeira sabedoria. (3) A famosa escola de Alexandria, segundo Eusébio já em funcionamento nos dias de São Marcos, teve como primeiro diretor (pelo menos é esse o mais antigo dos nomes que chegaram até nós) a Pantene, do $2 .^{\circ}$ século, estóico convertido, mestre de Clemente de Alexandria, seu sucessor na Escola, e um dos mais cultos dos apologistas cristãos. Este último considerava Crísipo, e não Aristóteles, o verdadeiro mestre da Lógica. ${ }^{(4)}$

A partir do séc. II, nota-se uma tendência para o sincretismo das duas lógicas. Galeno, (131-201), a quem devemos importantes comentários tanto sobre Aristóteles como sobre Crísipo, é um exemplo desse sincretismo, particularmente no vocabulário. O mesmo autor acima citado ${ }^{(5)}$ dá disso alguns exemplos, entre eles o de Galeno denominar "indemonstráveis" os modos da $1 .^{\text {a }}$ figura.

(3) Ver o Diálogo com o judeu Tryphon.

(4) cf [7-A] p. 92.

(5) Ibid. p. 125. 
Graças a Boécio, (480-525), passaram para a Idade Média os resultados finais da lógica estóica sobre os cálculos das variáveis proposicionais. Mas um longo e profundo silêncio de cinco ou seis séculos interrompe todas as pesquisas no campo da lógica. Pelo menos, dentro dos limites do nosso escasso conhecimento dessa época, muito pouco estudada até agora, por dificuldades de várias espécies.

Como seria de esperar, os escolásticos voltaram sua atenção para a lógica conceptual, obviamente preferida. Boschenski sugere que, mesmo quando emprenderam investigações em torno da lógica proposicional, fizeram-no provavelmente em conseqüência dos estudos dos Tópicos e talvez também da Hermeneia, e nunca como desenvolvimento da antiga lógica estóica. Segundo esse mesmo historiador, a Idade Média conheceu uma única lógica, que era a que todo o Baccalaureus artium tinha de saber usar com segurança. Aliás, ninguém ingressava na Faculdade de Teologia sem esse título.

É verdade que, já no final do séc. VIII (785), uma das mais representativas figuras do renascimento carolíngio, cuja obra, no sentir de Émile Bréhier, "teve real importância na direção intelectual de toda a Idade Média", a saber, Alcuino, encarregado por Carlos Magno de organizar os estudos no Império Franco, atribuiu à lógica, entre as sete artes liberais, importância excepcional: a Física correspondia ao Gênesis, a Moral aos Livros Sapienciais e a Lógica aos Evangelhos" (6).

Assim também, Raban Maur (780-856), atribui à dialética, com a qual aprendemos as diferentes formas de raciocínio, o papel de instrumento para a legítima compreensão da Escritura. (7)

É, contudo, somente nos séculos XI e XII, com a divulgação, entre os clérigos e leigos, de muitas obras de Aristóteles, até então desconhecidas, entre as quais uma boa parte do Organon, sobretudo, as Segundas Analiticas, que a dialética passa a ocupar indisfarçavelmente o lugar de destaque nos estudos escolásticos porque é ela que vai imprimir orientação às pesquisas teológicas. É verdade que notáveis lógicos como Berenger, na famosa disputa em torno das definições

(6) Grabmann, Geschichte der scholastischen Methode, vol. I p. 194. Apud [16] p. 47.

(7) De Inst. Cleric. L. III $\$ 16$. 
dogmáticas da santa eucaristia, do batismo, da imortalidade da alma, etc., se valeram de recursos fornecidos pela mesma lógica aristotélica utilizada pelos adversários. E contudo, em plena Idade Média, homens de incontestável honestidade intelectual e sincero amor à verdade, como Pedro Damiani, no começo do séc. XI, e Guilherme de Ockam, no começo do séc. XIV, reconheceram a necessidade de se recorrer a uma lógica diferente da do Estagirita para se discutirem as coisas relativas a Deus e às ligações que Ele mantém com o mundo que criou. É de fato interessante que Ockam se tenha valido, não poucas vezes, da lógica dos estóicos. E Robert Holkot, também no séc. XIV, não teve dúvida em afirmar: "Oportet ponere unam logicam fidei".

Mesmo quando se retomam as investigações no âmbito da lógica proposicional, é pouco provável, segundo opina Boschenski, que tivesse sido por influência estóica, a qual dormira também um longo sono de muitos séculos.

Todavia, é conveniente oferecer aos eventuais leitores deste artigo menos familiarizados com esses problemas, alguns dados mediante os quais lhes seja possível compreender a diferença fundamental entre a lógica aristotélica e a megárico-estóica .

Parece que foi Victor Brochard o primeiro a tentar reabilitar a lógica dos estóicos que chegou a ser, até, ridicularizada por críticos de renome como $\mathrm{K}$. Prantl, que não teve dúvida em caracterizá-la, na sua História da Lógica, como "um formalismo imbecil" e "uma imensa estupidez". Brochard mostrou que a Lógica de Aristóteles se baseava fundamentalmente em conceitos e termos, ao passo que a estóica lidava basicamente com proposições que se referiam a acontecimentos. Aristóteles, coerente com a sua metafísica, toda edificada sobre as idéias de substância e da organização hierárquica do mundo em classes, fez naturalmente a sua ciência trabalhar com termos ou conceitos. O verbo com o qual invariavelmente as proposições se formavam era o verbo ser. Se se diz, por exemplo: "Todos os homens são mortais", logo se percebem nessa simples proposição, que pode funcionar como premissa de um raciocínio silogístico, conceitos, termos, substâncias, classes. A Lógica dos megáricos e dos estóicos não estava interessada em classificar os seres nas suas espécies e gêneros respectivos. Também não se propunha colocar-se ao serviço de qualquer espécie de dogmatismo, como aconteceu com a do estagirita que acabou ditando até 
as normas do raciocínio teológico e bíblico. Com uma admirável antecipação e uma visão realmente genial das funções de um verdadeiro instrumento de trabalho científico, como é a lógica proposicional hoje, Zenão e Crísipo, seguindo as pegadas de Eubúlides e de outros megáricos, formalizaram a lógica em torno das proposições que exprimiam acontecimentos ou fatos: "Se o sol brilha, então é dia. Ora, o sol brilha, logo é dia."

O argumento, isto é, "um sistema composto de premissas e conclusão" que lembra o silogismo aristotélico, pode ser falso ou verdadeiro, segundo o indicar a conclusão ou qualquer das premissas. A conclusão pode não ser evidente e ser entretanto considerada válida por uma razão inteiramente estranha à estrutura do próprio argumento. O exemplo que Sextus Empiricus nos oferece neste caso é o seguinte: "Se Deus lhe disser que este homem será rico, ele será rico. Ora, este Deus disse-lhe que este homem será rico. Portanto, este homem será efetivamente rico" (8). Sextus diz que a conclusão é aceita não por causa da força do argumento em si, mas devido à fé no que Deus afirmou ${ }^{(9)}$. Mais adiante, voltarei a este exemplo.

A dialética estóica, segundo se depreende de Crísipo, trata

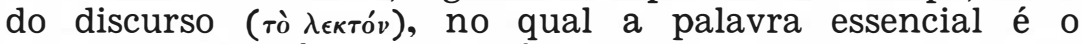
verbo ${ }^{(10)}$. Na lógica aristotélica, o verbo (sempre o verbo ser) tem sempre uma função copulativa e predicativa e visa a designar uma noção geral resultante da inclusão ou exclusão, total ou parcial, de indivíduos, espécies e gêneros. Não assim na dialética estóica, na qual se unem os dois elementos - separados em Aristóteles - a cópula e o predicado: unem-se indissoluvelmente exprimindo um acontecimento, e jamais qualidades classificatórias.

As proposições, na dialética estóica, formam também silogismos, como na aristotélica, mas estes têm, nelas, função inteiramente diversa, como logo se percebe do que acaba de ser dito.

\section{Paulo de Tarso}

Calcula-se que Saulo tenha nascido entre os anos 5 e 10

(8) Adv. Math .VIII 310-314.

(9) [70] pp. 61-62.

(10) [18] p. 69; [15] pp. 19-22. 
D.C., sendo, portanto, cerca de 9 a 14 anos mais jovem do que Jesus, cujo nascimento deve ter-se dado entre 7 e 5 A.C. . O futuro "apóstolo dos gentios" era judeu, natural de Tarso, onde estudou aos pés de Gamaliel (At 22,3) e onde formou o seu espírito.

Tarso foi a principal cidade da Cilícia na antigüidade, e conservava ainda nos dias de Paulo o mesmo prestígio. Situada às margens do Cnidos, chegou a ser um dos mais importantes centros comercias e culturais da Ásia Anterior. Fundada pelo legendário Sardanápalo, de acordo com uma antiga tradição, segundo outra por Senaqueribe (Eusébio, Cron. 1), os gregos chamaram a si esse privilégio quando a transformaram na mais notável polis de toda a região. Dion Crisóstomo (Or. XXXIII) e Libanius (Or. XXVIII 620) contam que, para os tarsenses do período da dominação grega, foi Perseu ou Hércules o fundador da cidade. Fato curioso é que o primeiro desses nomes corresponde também ao de um heroi assírio (Herod. VI 54) relacionado com a mitologia e a religião de muitos lugares da Ásia Menor; e o segundo era também o deus tírio a quem se atribuia a fundação de muitas colônias. Esse curioso sincretismo legendário reflete, sem dúvida, o caráter cosmopolita de Tarso desde os mais remotos tempos. De fato, pela sua privilegiada localização, veio essa cidade a desempenhar sempre um papel de liderança, qualquer que fosse o domínio político a cujo serviço estivesse. O seu nome figura na famosa inscrição do obelisco negro de Shalmaneser, como uma das grandes cidades conquistadas por esse rei, e chegou a ser a capital ocidental do vasto Império Assírio. Sob os selêucidas, mudaram-lhe o nome para Antioquia-sobre-o-Cnido, por causa de Antíoco IV Epifanes, que em 170 A.C. a reinaugurou como cidade grega. Por iniciativa desse rei, levas de judeus foram transferidas dos lugares em que viviam para as cidades da Ásia Menor, inclusive Tarso. Quando Pompeu conquistou a Cilícia em 66 A.C., Tarso ficou sendo a capital da Província. Nesse tempo, contava já com uma elevada porcentagem de judeus residentes. Antonio, como se sabe, recebeu nessa bela e rica libera civitas a visita de Cleópatra, que se admirou do seu luxo e esplendor.

Quando Saulo nasceu, Tarso era uma cidade movimentada e culta, em cujas instituições se refletiam as variadas e tão diferentes heranças da sua evolução, das quais, sem dúvida, a famosa universidade era a mais notável. O geógrafo Estrabão ( $\dagger 25$ A.D.), contemporâneo de Paulo, diz 
que a universidade de Tarso era então, em alguns aspectos, superior às de Atenas e Alexandria (Str. XIV.5.13). Nesse tempo era já Tarso o mais importante centro estóico de estudos filosóficos do mundo. Aliás, desde as origens do Pórtico, um grande número de sucessores de Zenão de Citium eram originários de Tarso, como o homônimo do fundador da Escola, que Crísipo, cujos pais eram também tarsenses, elegeu para seu substituto. De lá vieram também Antípater, Heráclides e Atenódoro, este último mestre e preceptor do Imperador Augusto. Era na Universidade de Tarso que o governo de Roma ia buscar os preceptores dos príncipes e dos futuros líderes do Nomen Romanum, e todos eles eram estóicos. É bem possível que Paulo, quando menino, tenha cruzado muitas vezes com Atenódoro nas ruas da sua cidade ${ }^{(11)}$.

A. Puech, no capítulo de sua História da Literatura Grega Cristã dedicado a Paulo, afirma que "Saulo, cognominado Paulo, provinha de uma família judáica, inatacável na sua ortodoxia, "fariseu filho de fariseus" (At 13,9), mas cidadão romano, nascido em Tarso, capital da Cilícia, cidade completamente helenizada, cidade "universitária", podemos dizer, a qual produziu um grande número de homens ilustres, retóricos, filósofos, sábios de toda a espécie [cf. Boehlig., H., Die Geisteskultur von Tarsus im augusteischen Zeitalter, 1913], foi, desde o começo, bem preparado para vir a ser o traço de união entre o cristianismo palestino e o mundo helênico e latino". (12)

Igualmente Adolfo Deissmann (13) reconheceu que Paulo foi um "helenista para os helenistas porque a língua e a alma do Helenismo haviam chegado até ele com o ar de Tarso". Mas eu estou certo de que Saulo não respirou essa atmosfera tão favorável só nas ruas, nas praças, no ambiente em que viviam todos, incluindo os estrangeiros, mas como participante das atividades normais de um jovem da sociedade constituída de cidadãos livres, educando-se para ser judeu entre os judeus, como queria certamente a sua família, e grego entre os gregos por vocação divina (Gl 1,15,16).

Não se pode esquecer o fato que Kierkegaard citou (14) de que circulava entre os judeus, na década de 60 A.D.,

(11) $[56-A]$ p. 17 .

(12) [80] vol. I pp. 178ss.

(13) [36] p. 41.

(14) Apud Lowrie, Kierkegaard, vol. I p. 167. 
o moto: "Maldito o que cria porcos, maldito o que ensina a seu filho a sabedoria grega". Mas nem todos os verdadeiros judeus se amedrontavam com tais fulminantes anátemas, como temos visto, e Paulo revelará mais tarde, em suas atitudes e palavras, as quais lhe custaram não pequenos aborrecimentos entre os "fundamentalistas" judaizantes do cristianismo primitivo, o espírito aberto que respirou em seu lar, à sombra do Taurus.

Dois fatos de inegável evidência corroboram a opinião, que defendo, de que Paulo recebeu esmerada educação judáica e helenística em Tarso. Esses dois fatos são: primeiro, a sua cultura e erudição, transparente em algumas das suas cartas e dos seus discursos, e, segundo, a sua cidadania romana. Victor Tcherikover, abundantemente documentado, mostrou que a cidadania romana era alcançada pelos filhos dos judeus que se matriculavam, mediante pagamento de determinada taxa, nos gymnasii, nome genérico das escolas de educação física e também das academias de filosofia que funcionavam nos edifícios daquelas ${ }^{(15)}$. Sobre a ampla educação de Paulo, opinam também favoravelmente Bultman (16) e Theodoro Zahn ${ }^{(17)}$.

Em que pese a opinião de Stauffer ${ }^{(18)}$, não creio que fosse necessário ao jovem judeu abandonar as tradições de seus pais nem ser infiel à orientação espiritual rabínica para que pudesse freqüentar as escolas gregas, como um verdadeiro éphebo. É certo que, como assinala o mesmo autor, muito da dialética paulina tinha raízes rabínicas, mas, como pretendo a seu tempo demonstrar, é fora de dúvida que o apóstolo dos gentios aprendeu também a usar a dialética estóica.

Exemplo eloquente da penetração da cultura helenística entre os judeus são alguns dos chamados livros apócrifos ou pseudo-epígrafos, principalmente o IV Livro de Macabeus, escrito por um judeu formado na Lei e nos Profetas (18,10.13-19), mas detentor de uma sólida educação grega que se manifesta no vocabulário, no estilo, no método e na temática do seu livro. O que mais de perto nos convém ressaltar, todavia, é a sua indisfarçável dialética estóica. E

(15) [101] pp. 312ss; 350ss; 511ss; 526ss.

(16) [23] pp. 130-131; [24] I p. 67 e 229ss.

(17) [110] vol. I pp. 50ss.

(18) [98] pp. 35-36. 
entretanto, IV Macabeus é uma espécie de homilia escrita só para os judeus... (19)

Ignoramos se Paulo teria conhecido este livro. De qualquer forma, a semelhança de estilo e de argumentação indicam que o menos que se pode inferir é que ambos os autores beberam das mesmas águas.

Tinha, pois, razão o apóstolo quando afirmou ao tribuno de Jerusalém: "Sou judeu, cidadão de Tarso, cidade não pouco célebre da Cilícia" (At 20,39) .

No ano 33 ou 34, Saulo assistiu ao martírio de Estêvão (At 7,$58 ; 8,1$ ) e participou, de certo modo, da sua execução porque se dispos a vigiar as túnicas dos apedrejadores que delas se desembaraçavam para com maior agilidade realizarem a sua triste tarefa. Muitos autores têm relacionado esse fato com a conversão de Saulo ao Evangelho que perseguia, pouco depois, quando, a caminho de Damasco, aonde se dirigia com o propósito de descobrir cristãos e levá-los presos a Jerusalém, se defrontou, segundo repetidas vezes contou, com o Cristo ressurreto. A forte impressão causada no ânimo do fanático perseguidor pelo desassombrado testemunho do proto-mártir do cristianismo explicaria psicologicamente muito do processo da sua conversão. Pode ser, pelo menos em parte, que essa teoria seja verdadeira. Porém, o que não se pode deixar de ter em mente na presente pesquisa, é o próprio conteúdo do discurso daquele diácono eleito pelos demais discípulos, juntamente com outros seis, para se encarregar da "assistência social", como hoje diríamos, para que os apóstolos pudessem dedicar-se inteiramente ao "ministério da Palavra".

O instrumento mediante o qual se operou a extraordinária transformação espiritual do sábio fariseu não foi apenas a serenidade e a paz com que Estêvão enfrentou a morte que lhe deram os inimigos do Evangelho que pregava, mas também o teor do seu discurso. Esse pormenor não pode ser esquecido. A reiteirada referência que o mártir fez aos fatos e aos acontecimentos históricos do seu povo, que era também o daqueles que o perseguiam, e a interpretação daqueles fatos e acontecimentos como atos poderosos de Deus, ambas feitas por Estêvão não só com piedade religiosa, mas com coerência e limpidez cristalina ao mesmo tempo, cairam

(19) [79] pp. 216ss. 
como um clarão noético na inteligência de Saulo e ficaram martelando a consciência claquele homem que sabia tão bem raciocinar com a relação lógica dos "indemonstráveis" (ảvomóo $\left.\delta_{\epsilon \kappa} \tau o l\right)$. Com os estóicos havia ele aprendido que ser capaz de relatar os fatos históricos não significava necessariamente conhecê-los. O conhecimento só advinha da sua correta interpretação e compreensão. Tal conhecimento verdadeiro dos acontecimentos correspondia a maior proximidade de Deus, a uma como que maior afinidade com Ele, porque nada ocorre fora do âmbito da sua vontade, e o "querer os acontecimentos como eles se dão", como escrevu Epiteto (Encheir. 8) - (Mais literalmente e no seu contexto: "Não peças que as coisas aconteçam como desejas, mas deseja que aconteçam como são") - implica em viver em comunhão com Deus, pois era esse, no fundo, o sentido do aforismo de Zenão: "Vive em harmonia com a naturereza". Crísipo disse a mesma coisa. E o mesmo Zenão considerava a natureza como divina. (Stob., Égl. II 132; Cic., $1 .^{a}$ S Acad. XLII) .

Por outro lado, Paulo teria reconhecido a lógica estóica na forma de argumentar de Estêvão, cujo nome, como os dos outros diáconos, era grego e, de acordo com a informação dada por Lucas (At 6, 8-11), ele fazia parte do grupo de helenistas de Jerusalém, e possivelmente da sinagoga deles. Nada mais sabemos de Estêvão, mas é sintomática a relação que Paulo, no discurso em sua defesa perante o tribuno de Jerusalém, fez entre o mártir de nome gentílico e a comissão que recebeu de Cristo no caminho de Damasco: "Vai, porque hei de enviar-te aos gentios de longe" (At 22,20.21).

Não creio abusar da imaginação sugerindo que a argumentação de Estêvão, calcada em relacionamento de fatos históricos, produziu grande impacto no espírito de Saulo, e foi isso que, provavelmente, no momento oportuno, levou o apóstolo dos gentios a utilizar a mesma forma de raciocínio na prédica e na correspondência pastoral. Aliás, no fundo, como na forma, a argumentação de ambos é idêntica. Nem Paulo nem Estêvão se defenderam definindo doutrinas, apelando para a força dos conceitos exatos ou para a ortodoxia dos seus dogmas. Limitaram-se a recordar a história do povo de Israel e a relacioná-la com Cristo. Como bem disse Sabatier ${ }^{\left({ }^{\circ}\right)}$ a respeito do discursto de Estêvão, "as grandes épocas da história do seu povo forneceram-lhe as grandes

(20) [89] pp. 21-22. 
divisões do seu sermão". Algo semelhante vamos encontrar também em Paulo.

Mas não foi apenas a lógica dos eventos citados pelo diácono em sua defesa que causou a transformação total do pensamento e da vida de Saulo. Foi o grande evento da sua própria vida: o encontro pessoal com o Cristo ressurreto no caminho de Damasco. O clarão tão forte que o cegou temporariamente veio acompanhado da própria voz de Jesus: "Saulo! Saulo! Por que me persegues?" De Damasco, aonde chegara não mais como perseguidor, partiu para a Arábia, onde permaneceu três anos em meditação (At 22, 10ss; 26, 12ss; Gl 1, 18ss) . Depois, foi a Jerusalém para estar com Pedro e Tiago, irmão do Senhor, por quinze dias, e logo partiu para a sua cidade natal (At 9, 30) .

O texto de Lucas deixa cair o silêncio sobre o que aconteceu durante os longos catorze anos decorridos até o seu aparecimento entre os apóstolos para, com segurança e base nas Escrituras, e também pelo que aprendeu dos discípulos de Cristo que contactara, lutar por uma interpretação no seu entender mais legítima do mesmo Evangelho que antes perseguira e que, agora, se tornara a própria razão de ser da sua vida: "Para mim o viver é Cristo" (Flp 1,21); "Vivo, não mais eu, mas Cristo vive em mim" (Gl 2,20) .

Foi em 48 ou 49 que Paulo esteve nessa reunião com os demais apóstolos (At 15) . Fizera antes a sua primeira viagem missionária, em cujo itinerário estava Tarso. A segunda, logo após a conferência de Jerusalém, levou-o de novo para a Cilícia (49-52) (At 15,40-51), de onde partiu para o norte até Troas. Deu então o passo de consequências históricas incalculáveis: penetrou na Europa, levando consigo o Cristianismo. Chega até Atenas onde discute com filósofos estóicos e epicureus (At 17) .

Por volta de 51, começam a aparecer as epístolas de Paulo. As duas primeiras nesse mesmo ano, $1 .^{a}$ e $2 .^{a}$ aos Tessalonicenses. Retorna a Jerusalém em 52 e parte para a sua terceira viagem missionária (53-58). Vai a Éfeso e a Corinto. Escreve aos Coríntios três cartas, uma das quais se perdeu, e aos Filipenses e aos Romanos. É provável que a que escreveu aos Gálatas date dessa mesma época. Tiago, "o irmão do Senhor", está em Jerusalém, à testa da comunidade local. Por esse tempo, escreveu Tiago a sua epístola aos judeus convertidos da diáspora. Paulo foi preso por 
ocasião da festa do Pentecostes, em Jerusalém, e foi levado para Cesaréia, em cuja cadeia permaneceu dois anos (58-60), ao cabo dos quais, tendo, perante Festo, apelado para César - recurso a que a sua condição de cidadão romano lhe dava direito - foi levado prisioneiro a Roma, onde ficou até 63, quando alcançou a liberdade, embora por pouco tempo. Na prisão, escreveu as epístolas aos Efésios e aos Colossenses e o comovente bilhete a Filemon. Nessa altura, Pedro escreveu a sua primeira carta, e Marcos compôs o Evangelho que traz o seu nome, porém, que é, na realidade, uma síntese dos sermões que ouvira daquele apóstolo. Paulo retorna a Éfeso em 65, ano em que Sêneca se suicidou por sentença imperial. Alguns estudiosos admitem que a $1 .^{a}$ carta a Timóteo e a endereçada a Tito datam desse tempo. É possível que os Evangelhos de Mateus e de Lucas, bem como os Atos dos Apóstolos tenham sido escritos nesse mesmo ano.

Não é improvável que São Paulo tenha então conseguido ir à Espanha, como sempre desejou $(\mathrm{Rm} 15,28)$. Em 67 é novamente levado preso para a capital do Império, e alí, talvez com São Pedro, é, segundo a tradição, martirizado.

\section{São Paulo e as formas canônicas do} silogismo estóico

Os resultados da pesquisa feita sobre o glossário mais característico dos textos estóicos e o vocabulário de São Paulo, para o que me vali principalmente das anotações de B. Mates, na sua Stoic Logic, e de Jean Brun, em Les Stoiciens, e da Concordance to the Greek Testament, de W. F. Moulton e A. S. Geden, da Hand-Konkordanz zum griechischen Neuen Testament de A. Schmoller e da Exhaustive Concordance of the Bible, de James Strong, - não cabem num trabalho da natureza deste, mas espero publicá-los noutra oportunidade e noutro lugar. Igualmente foge ao interesse desta revista o estudo comparativo dos processos paulinos e estóicos de exposição argumentativa, como, por exemplo, o emprego das perguntas e dos paradoxos. Como ilustração, menciono o caso da semelhança entre o texto de Sextus Empiricus anteriormente citado ${ }^{(23)}$ e três paralelos de São Paulo (1 Co $1,8.9$; 10,13; 2 Co 1,18-20) .

(21) [110] vol. I pp. 53 e 71.

(22) Str. 19.5.

(23) cf. (8). 
No passo de $\mathbf{S}$. Empiricus, o raciocínio leva à conclusão certa e indiscutível de que certo homem virá a ser rico. Trata-se de um dos textos estóicos nos quais se argumenta com vistas ao porvir.

Haveria muito que dizer sobre esses lances de antecipação do futuro encontradiços nalguns textos estóicos - e muitos já o têm feito com mestria. Entendo que tal pesquisa seria de interesse não só científico, mas também teológico, em particular no que toca ao problema da predestinação em São Paulo.

Interessa-nos aqui, porém, a referência ao caso citado por Sextus Empiricus por duas outras razões. Por um lado, pela interferência de Deus como argumento lógico e, por outro, pela peculiaridade dessa intervenção divina manifestada no vocabulário usado. Em ambos os aspectos, descobre o pesquisador uma surpreendente afinidade com textos paulinos. Tanto mais surpreendente quando se constata a absoluta ausência de contato ou dependência entre os mesmos escritores. O que aí se nota, é, sem dúvida, uma fonte comum de inspiração no processo lógico com base, evidentemente, nalguma metafísica ou teologia. O estudo pormenorizado dessa questão particular nos levaria para longe demais dos objetivos deste trabalho. Será suficiente indicar dois ou três pontos de maior relevância, em relação aos dois aspectos mencionados.

O texto de Sextus Empiricus ilustra o caso de certeza a que o raciocínio leva sem que exista, para tanto, nenhuma força nas premissas da argumentação. A tranqüila conclusão a que se chega é oferecida pela singela afirmação contida numa das premissas de que o anunciado fato futuro

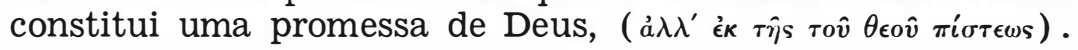

É preciso não esquecer que, para o sábio estóico, só o presente tem realidade. O passado e o futuro não existem realmente, um porque já não é, o outro porque ainda não é; mas, para Deus, tanto um como outro estão dissolvidos no eterno presente, que só ele conhece. Por isso, no estoicismo, o Destino e a Providência se identificam. Portanto, a promessa de Deus é a garantia do conhecimento do futuro e da tranqüila esperança da sua realização.

Os textos de São Paulo acima citados são os seguintes: "O qual (Jesus Cristo) vos confirmará também até o fim, 
para serdes irrepreensíveis no dia de nosso Senhor Jesus Cristo. Fiel é Deus, pelo qual fostes chamados para a comunhão de seu Filho, Jesus Cristo, nosso Senhor". (1 Co 1,8.9). "Não veio sobre vós tentação senão humana; mas fiel é Deus que vos não deixará tentar acima do que podeis, antes com a tentação dará também o escape para que a possais suportar." (1 Co 10,13). "Antes, como Deus é fiel, a nossa palavra para convosco não foi sim e não. Porque o Filho de Deus, Jesus Cristo, que entre nós foi pregado por nós, [...] não foi sim e não, mas nele houve sim. Porque todas quantas promessas ha de Deus, são nele sim." (2 Co 1,18-20).

Ora, a despeito de a teologia de São Paulo ser totalmente diversa da do estoicismo, há nesses textos citados de um e de outro autor, algo idêntico: a certeza das coisas futuras que predizem depender exclusivamente da promessa de Deus, o qual é fiel. O locus classicus da teologia paulina nesse respeito está em $\mathrm{Rm}$ 4,18: “Como está escrito: Por pai de muitas nações te constitui" (a Abraão) perante aquele no qual creu, a saber, Deus, o qual vivifica os mortos, $e$ chama as coisas que não são como se já fossem. O qual (Abraão), em esperança, creu contra a esperança, que seria feito pai de muitas nações, conforme o que lhe fora dito [...] e não $d u$ vidou da promessa de Deus." (Rm 4,17-20) . A clareza do texto dispensa qualquer comentário.

O segundo dos aspectos acima mencionados é de natureza lingüística, e o fato de ambos os autores terem usado o mesmo idioma facilita o estudo.

O substantivo $\pi i \sigma \tau \iota \zeta$ (gen. $\pi i \sigma \tau \epsilon \omega s$ ) que aparece no texto citado de Sextus Empiricus é o mesmo que se encontra também no Novo Testamento, em 24 dos seus 27 livros. Treze são as epístolas de Paulo, e em todas o termo ocorre, nada menos que 138 vezes das 234 em que é empregado. Só quatro vezes o termo se refere a Deus no sentido de fidelidade: fidelidade de Deus. Todas provêm da pena do apóstolo Paulo, em dois versículos da epístola aos Romanos (1, 17 e 3,3$)$.

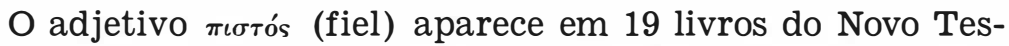
tamento (dos quais 10 são epístolas de Paulo, 64 vezes ao todo; dessas, 33 por São Paulo. Apenas 8 vezes se usa 0 termo em referência a Deus e 5 em referência a Jesus Cristo, sendo Paulo responsável por 4 no primeiro caso (em $1 .^{a}$ e $2 .^{a}$ Coríntios e 1. ${ }^{a}$ Tessalonicenses) e 2 no segundo (em 2. ${ }^{a}$ Tessalonicenses e 2. ${ }^{a}$ Timóteo) . 
Examinemos os textos. Em 1 Co 1, 8.9, Paulo afirma que os crentes a quem a carta se dirige serão confirmados por Jesus Cristo para serem irrepreensíveis no dia do Senhor. Em resposta à possível pergunta: Que garantia teremos de que

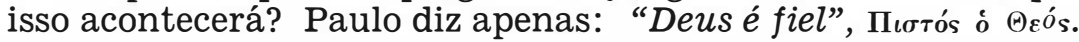

Em 1 Co 10, 13, tendo advertido os leitores de que ninguém deve imaginar-se isento de cair em tentação, confiando nas suas próprias forças, acrescenta que Deus não deixará que alguém seja tentado acima de suas forças, e o ajudará para que possa suportar a tentação. E lembra-lhes, como garantia: Deus é fiel.

Em 2 Co 1, 18, Paulo empenha a sua palavra de que era verdadeira a sua pregação, e o seu procedimento para com os coríntios era sincero e coerente, no sentido de que entre o teor da mensagem e o comportamento do mensageiro não havia contradição, pois não havia falsidade nem ambigüidade naquele de quem a sua pregação falava, a saber, Jesus Cristo, o Filho de Deus, porque Deus é fiel e cumpre todas as suas promessas. É interessante notar que tanto Paulo como Empiricus empregam a mesma palavra para promessa: $\dot{\epsilon} \pi a \gamma \gamma \epsilon \lambda i ́ a$.

Plummer, no seu excelente comentário à $2 .^{\mathrm{a}}$ epístola de Paulo aos Coríntios, classifica este argumento de "ethical congruity", e cita a paráfrase de Crisóstomo: "Não duvideis do que procede de Deus, porque o que é de Deus, não pode ser falso ${ }^{(24)}$. Creio que, por um lapso, Plummer, que noutros casos assinala paralelismo da forma e da linguagem de Paulo com a estóica, não o faz aqui.

As formas canônicas do silogismo estóico são:

1) Se o primeiro, o segundo; ora, o primeiro, portanto, o segundo. (Modus ponendo ponens).

2) Se o primeiro, o segundo; ora, não o segundo; logo, não o primeiro. (Modus tollendo tollens).

(24) p. 35 .

(25) Sextus Empiricus, Hyp. Pyrrh. II 157ss; Adv. Math. VIII 224 ss.: Diógenes Laércio, Vitae VII 79-81. 
3) Não simultaneamente o primeiro e o segundo; ora, o primeiro portanto, não o segundo.

(Modus ponendo tollens).

4) Ou o primeiro, ou o segundo; ora, o primeiro; portanto, não o segundo.

(Modus ponendo tollens).

5) Ou o primeiro, ou o segundo; ora, não o segundo, portanto, o primeiro.

(Modus tollendo ponens).

A luz do que até agora ficou dito, passemos sem demora ao exame de alguns textos do apóstolo. Não entraremos, evidentemente em questões exegéticas e hermenêuticas mais extensas e profundas, exceto na medida em que for isso necessário à compreensão da própria argumentação de São Paulo. Os textos foram escolhidos com o propósito de ilustrar o emprego de cada uma das formas canônicas da lógica estóica.

1) Gl 2,17: Se nós, que procuramos ser justificados em Cristo, nós mesmos somos também achados pecadores, é porventura Cristo ministro do pecado? De maneira nenhuma!

O texto traduz o enfático "NÃO!" apostólico, reagindo contra a inferência que desvirtuava totalmente o verdadeiro sentido da sua mensagem, mas que os seus críticos pretendiam, sofismando, apresentar como legítima. A mensagem, entretanto, era na verdade muito simples e muito clara. Está resumida no versículo anterior, no qual o apóstolo expõe seu pensamento assim: "Sabendo, que o homem não é justificado pelas obras da lei, mas pela fé em Jesus Cristo, temos também crido em Jesus Cristo, para sermos justificados pela fé de Cristo, e não pelas obras da lei; porquanto pelas obras da lei nenhuma carne será justificada. O homem é, segundo São Paulo, justificado pela graça de Deus em Jesus Cristo, mediante a fé, e não pelas obras da lei. Se Deus, pois, nos oferece, em Cristo, a justificação, carecerá de sentido qualquer esforço nosso de pretender alcançar a misericórdia de Deus através de nossas boas obras (subentendida a prática da lei). Pior do que isso: se o fizéssemos, seríamos "separados de Cristo", diz São Paulo (Gl 5,4). Existe total antagonismo entre, de um lado, a graça e a fé, e, de outro, as obras da lei: Cristo teria morrido debalde (Gl, 2,21) . 
Ora, é absurdo concluir da doutrina de Paulo que Cristo se torna "ministro do pecado", pois aqueles que ele justifica continuam pecadores por serem dispensados de cumprir a lei para a sua justificação. Aliás, a própria mensagem apostólica, central desta epístola, como também da que foi endereçada aos Romanos, implica no fato de que os que vivem em Cristo, na medida em que dele mais se aproximam, se reconhecem pecadores, e por conseguinte, sentem-se, em consciência e com humildade, necessitados, sempre, da graça e da misericórdia de Deus.

O paralogismo, que o apóstolo repele, pode ser formulado da seguinte maneira: [se nós (pecadores) procuramos ser justificados em Cristo (e o somos porque ele deu a sua vida por nós e ressuscitou para nossa santificação) e entretanto somos achados pecadores (porque não cumprimos a lei) $]=\mathrm{p}$, segue-se que [Cristo é ministro do pecado] $=\mathrm{q}$. Temos, pois, o seguinte:

$$
\text { [ ( }(\mathrm{p} \cdot \mathrm{q}) \cdot \mathrm{p}) \supset \mathrm{q}]
$$

O apóstolo respondeu a esse falso raciocínio com estas palavras: De maneira nenhuma! $\sim[((p . q) \cdot p) \supset q]$

O êrro do raciocínio não reside na forma, mas na matéria do silogismo. O preconceito judaizante que animava Pedro e seus companheiros cegava-os para a compreensão plena do significado do acontecimento, no tempo histórico do rei Herodes e de Pôncio Pilatos, da encarnação do Verbo, que é um ato da graça de Deus, da vida, morte e ressurreição de Jesus Cristo, pois continuava exigindo dos conversos a obediência à lei.

2) Essa teologia é condenada por Paulo, pois que levava à "aniqüilação da graça de Deus": "Não aniqüilo a graça de Deus; porque, se a justiça provém da lei, segue-se que Cristo morreu debalde."

[A justiça provém da lei] $=p$ e [Cristo morreu por nós] $=\mathrm{q}$ são duas proposições incompatíveis. Ora, se se aceita como verdadeira a primeira proposição, nega-se a segunda. Temos, pois, aqui um exemplo da terceira forma canônica: Não simultaneamente o primeiro e o segundo; ora, o primeiro, portanto não o segundo. Modus ponendo tollens: $\quad[(\sim(p . q) \cdot p) \supset \sim q]$

3) 1 Co 15, 12.13: Ora, se se prega que Cristo resus- 
citou dos mortos, como dizem alguns dentre vós que não há ressurreição de mortos? E, se não há ressurreição de mortos, também Cristo não ressuscitou.

Temos, no versículo 13, outro exemplo da primeira forma canônica: [Não há ressurreição] $=$ p. [Cristo não ressuscitou $]=\mathrm{q}$

$$
[((p \supset q) \cdot p) \supset q]
$$

Há, portanto, incoerência em se pregar que a nossa esperança se baseia na ressurreição de Cristo, e que Cristo de fato ressuscitou (como Paulo irá demonstrar no capítulo 15 desta mesma carta), e, ao mesmo tempo, afirmar que não há ressurreição de mortos (como está no versículo 12). Temos, pois, aqui um bom exemplo da segunda forma: [Cristo ressuscitou $]=\mathrm{p}:$ [os mortos ressuscitam $]=\mathrm{q}$.

Como não percebem os coríntios, a quem o apóstolo alude no texto, que existe absoluta incompatibilidade entre a afirmação de $p$ e a negação de $q$ ? $\quad[((p \supset q) \cdot \sim q) \supset \sim p]:$ Se o primeiro, então o segundo; ora, não o segundo; portanto, não o primeiro. Modus tollendo tollens.

4) Gl 3,18.19: Se a herança provém da lei, já não provém da promessa: mas Deus, pela promessa, a deu gratuitamente a Abrã̃o. Logo, para que é a lei? Foi ordenada por causa das transgressões, até que viesse a posteridade a quem a promessa tinha sido feita.

Muitos objetavam ao conteúdo da pregação de Paulo o seguinte: Se a justificação vem exclusivamente da graça de Deus, sem as obras da lei, para que a lei? Paulo responde (Gl 3,24) que ela nos serviu de paidagogos (palavra que, no original, significa o servo, ou escravo, que mantinha na disciplina a criança entregue aos seus cuidados, e a levava ao mestre) . Assim, a lei teve a mesma função: disciplinava os que criam na promessa feita a Abraão e guiava-os ao autor da promessa.

Ora, a promessa é feita a Abraão primeiramente, e depois a todos os que crêem, e por isso é o velho patriarca chamado o "pai dos crentes" (Rm 4,11; Jo 8,39). Estes, os que crêem, não são os que são escravos da lei, mas os que, crendo, vivem na liberdade dos filhos de Deus (Gl 3,26-4,9). Pela promessa, Deus fez a Abraão seu herdeiro, gratuitamente. Portanto, a fé na promessa, e não a prática da lei, 
é o instrumento mediante o qual ele, como todos os que crêem, recebem a herança prometida. Logo, [a herança provém da promessa] $=\mathrm{p}$ e [a herança provém da lei] $=\mathrm{q}$ se excluem mutuamente. Por conseguinte, [( $(\mathrm{pWq} . \mathrm{p}) \supset$ -q]: Modus ponendo tollens.

5) $\mathrm{Rm}$ 6,15-16: Não sabeis vós que a quem vos apresentardes por servos para the obedecer, sois escravos daquele a quem obedeceis, ou do pecado para a morte ou da obebediência para a justiça?

Por meio desta linguagem metafórica, Paulo responde aos detratores da sua doutrina. Estes sofismavam defendendo o próprio "interesse" de se aproveitarem da liberalidade da doutrina da graça de Deus que acabaria por esquecer tudo e tudo perdoar, a fim de, tranqüilamente, retornarem à ignomínia da sua ominosa existência anterior ao seu conhecimento de Cristo, e coonestarem a sua vida de impiedade. Sofismavam também para impugnar, argumentando $a b$ absurdum, a doutrina apostólica de que, uma vez abundando o dom da graça de Deus sobre todos quantos por ela são alcançados, todos serão justificados perante Ele (Rm 5, 1-21). Paulo resume tal raciocínio nestes termos: "Que concluiremos? Permaneceremos no pecado para que se multiplique a graça?" (Rm 6,1), e também nestas palavras: "Pecaremos porque não estamos debaixo da lei, mas debaixo da graça?" (Rm 6,15) .

C. H. Dodd, no seu admirável livro sobre esta epístola, escreveu este feliz comentário: "Paulo disse o suficiente para nos convencer de que não está inventando uma teoria ou dando aso a que se fantasie em torno do que ele ensina sobre a salvação por intermédio de Cristo. Ele se mantém fiel à experiência e aos fatos. Tranqüilamente, pressupõe que seus leitores entendam o que ele quer dizer com a expressão: "viver e mover-se alguém numa nova esfera de vida" (26).

Viver na nova esfera de vida significa participar do corpo de Cristo, não apenas como membros da comunidade, que é a Igreja, mas individualmente, na participação pessoal da vida, morte e ressurreição do Senhor, de que o batismo é sinal. Portanto, em ambos os casos - tanto por sermos membros do corpo de Cristo (por que morremos e ressusci-

(26) [41] p. 95. 
tamos com ele), como por estarmos integrados, por essa mesma e única razão, na comunidade dos crentes - é inconcebível que possamos pretender aproveitar-nos da infinita misericórdia de Deus revelada em Cristo para permanecermos no pecado. Podemos formalizar a alternativa, subentendida no texto, desta maneira: Viveremos para o pecado, por uma das seguintes razões: ou porque estamos sob o império da lei ou porque vivemos debaixo da jurisdição da graça. Ora, fica, certamente, eliminada a segunda. Logo, permanece a primeira. A enfática negativa de Paulo -

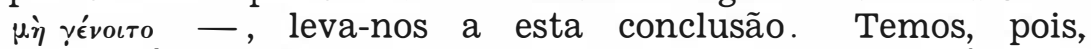
no versículo 15 , outro exemplo da $5 .^{a}$ forma canônica: $[((\mathrm{pWq}) . \sim \mathrm{q}) \supset \mathrm{p}] . \quad$ Modus tollendo ponens .

6) Paulo destrói, assim, o raciocínio faccioso e oportunista dos que torciam as suas palavras. Agora, no verso 16, ele reafirma, mediante o uso da adversativa $\ddot{\eta}^{\prime} \tau \iota . . . \ddot{\eta}^{\prime}$, o que no v. anterior dissera. Formalizando o silogismo, temos: "Sois escravos daquele a quem obedeceis: ou do pecado para a morte ou da obediência para a justiça". O silogismo enquadra-se na $4^{\text {a }}$ forma canônica: Vós não podeis ao mesmo tempo servir ao pecado, que leva para a morte, e à justiça que conduz à vida: ou a um ou ao outro desses senhores tereis de servir. Ora, se escolhestes o primeiro (com a agravante do sofisma! dizemos nós) sois dele escravos, e, por conseguinte, não possuis a liberdade que experimentam os servos da justiça nem compreendeis o que significa viver na nova esfera de vida. Assim temos: $[((\mathrm{pWq}) \cdot \mathrm{p}) \supset \sim \mathrm{q}]$. Modus ponendo tollens.

7) 1 Co 4,21: Que quereis? Irei ter convosco com vara ou com amor e espirito de mansidão?

Trata-se, neste caso, de argumentação não sobre questões teológicas, mas pastorais. O apóstolo, nesta carta, censura os coríntios por se terem afastado dos padrões de vida cristã: dissensões constantes, contendas por causa da liderança da comunidade, retorno de alguns aos antigos costumes pagãos, à idolatria, à avareza, à maledicência, à prostituição. A situação era tão grave que, numa carta anterior (da qual, infelizmente, não nos resta senão, talvez, um pequeno trecho hoje incluido na atual $2{ }^{a}$ carta (2 Co 6,14-7,1), Paulo se dirigira à Igreja em termos enérgicos e duros, do que muitos se queixaram. Pelo que o apóstolo ficou sabendo, temiam em Corinto a sua anunciada visita... Escreve-lhes então: Que esperam de mim? Que lhes dê os para- 
béns? Que os elogie? Ou que ao menos fique em silêncio, fingindo que nada sei? Que apareça aí, numa visita social e cordial, como um pastor bonzinho, "em amor e espírito de mansidão"? É evidente que não é isso que Paulo entende por autêntico ministério pastoral: o verdadeiro pastor usa também a vara, quando necessário. Eles que contassem, portanto, com a justa reprimenda.

A argumentação de São Paulo culmina com esta apóstrofe em forma interrogativa, tão de seu vezo: $\tau^{\prime} \theta \theta^{\prime} \lambda \epsilon \tau \epsilon$; (Que quereis?) O ri deixa a resposta a quem a pergunta se dirige, mas o contexto mostra que só uma podia ela ser: ' $\epsilon \nu$ jáßjo (com vara!).

Por conseguinte, temos, neste caso, outro exemplo da quinta forma canônica: $[((p W q) \cdot \sim q) \supset p]$.

A base teológica do raciocínio dos estóicos e de São Paulo: semelhanças e diferenças

Na sua História da Filosofia, Émile Bréhier, diz que as raízes do pensamento estóico eram semíticas. Com efeito, a idéia de um Deus todo poderoso que governa o destino dos homens e das coisas está longe de ser helênica. O deus das orgias místicas de Dionísio, o deus que Aristóteles concebia imóvel e distante dos seres humanos, e o deus idéia pura de beleza e perfeição racional absoluta, mas sem bondade moral, de que Platão fala nos seus diálogos, diferem todos do deus dos estóicos. Zenão - escreve Bréhier - é antes de tudo o profeta do Logos, e a filosofia é para ele e seus seguidores, a ciência das coisas divinas e humanas, isto é, de tudo o que é racional, vale dizer, da natureza. A filosofia dos estóicos não pretendia eliminar o dado sensível em favor da Razão, mas, ao contrário, procurava levar a Razão a "tomar corpo nele". E ajunta Bréhier, aliás um dos mais claros expositores da filosofia do Pórtico: "Onde Platão acumula diferenças para fazer-nos sair da caverna, o estóico não enxerga senão identidades. Enquanto, na Bíblia, a história humana é, em si mesma, um drama divino, os mitos e as lendas dos gregos permanecem à margem da história dos homens. Assim, também no estoicismo, é precisamente nas coisas sensíveis que a razão adquire a plenitude da sua realidade, ao passo que, no platonismo, o inteligível fica à margem do sensível." 
Essa penetrante análise das raízes religiosas do pensamento estóico, abre-nos o caminho para a compreensão do fundamento da sua lógica, assim como a dialética de Platão e a lógica de Aristóteles tinham seu fundamento nas suas respectivas concepções metafísicas. Como escreve o mesmo Bréhier no livro que tenho citado freqüentemente sobre a

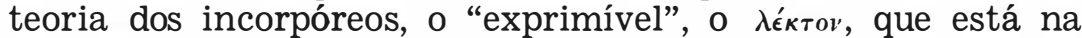
base de toda formulação dialética estóica, "é o atributo ou o acontecimento, seja com o sujeito, seja sem o sujeito." (27) "O exprimível não é qualquer espécie de representação racional, mas unicamente a do fato e do acontecimento. Como tal, ele forma a matéria de toda a lógica" (28)

Neste ponto, em que sublinhamos a grande semelhança entre as bases sobre que se construiam os raciocínios lógicos tanto dos estóicos como do apóstolo Paulo, torna-se necessário assinalar uma grande diferença. Os estóicos ${ }^{(29)}$ falavam, é bem verdade, da ação de Deus no mundo, mas a imanência na qual se processava aquela atividade divina nenhum caráter redentor possuia. Portanto, nenhuma relação nem semelhança existia entre essa divina atividade e os atos da graça de Deus, de que está cheio o Novo Testamento.

Num belíssimo trabalho sobre a paternidade de Deus ${ }^{(30)}$, insiste Paul Ricoeur em afirmar que o filósofo, quando reflete sobre a religião, deve confrontar-se antes com o exegeta do que com o teólogo". "... a exegese — diz ele exorta-nos a não separar as figuras de Deus das formas do discurso nas quais essas figuras aparecem. Entendo por forma de discurso - continua - a narrativa ou a saga, o mito, a profecia, o hino e o salmo, o texto sapiencial, etc." O professor Ricoeur investiga um problema diferente daquele de que aqui se trata, mas o princípio que ele estabelece é absolutamente válido para a nossa pesquisa. Ele termina o parágrafo dizendo: "Não indagamos o que é que, por abstração teológica, a Bíblia diz sobre Deus, mas sim como é que Deus surge nos diversos discursos que estruturam a Bíblia".

Apliquemos este método à nossa leitura dos textos paulinos. Tomemos, por exemplo, as palavras que Paulo

(27) [15] D. 22.

(28) [15] p. 23.

(29) cf. [44]

(30) [83-A] p. 233. 
proferiu na sinagoga de Antioquia da Pisídia (At 13,16-41) . Convidado a dizer ao povo ali reunido "alguma palavra de consolação", o apóstolo pronunciou uma exortação que de fato, outra coisa não foi senão a narrativa de episódios da história do povo de Israel interpretados conforme, aliás, as melhores tradições proféticas do Velho Testamento como atos de Deus. Descontando-se os trechos contextuais ou de citações paralelas do Velho Testamento, encontramos nos versículos 17-23 e 30-32 (dez versículos apenas) nada menos que 14 diferentès verbos de ação relacionando acon-

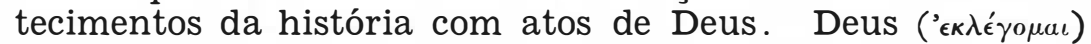
escolheu os pais, ( $\dot{\alpha} \psi{ }^{\prime}(\omega)$ exaltou o povo, tirando-o (' $\epsilon \xi a ́ \gamma(\omega)$

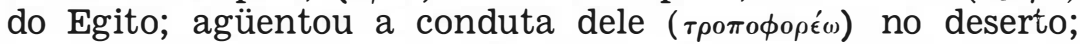

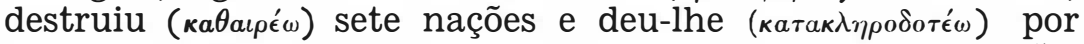
herança a terra delas; organizou o povo como nação, começando com o governo dos juízes que Deus lhe deu $\left(\delta \kappa^{\prime} \epsilon^{\prime}(\omega)\right.$ ), e mais tarde instituiu a monarquia dando-lhe (idem) Saul por rei, que logo afastou $\left(\mu \in \theta^{\prime} \sigma \tau \eta \mu\right)$, substituindo-o por Davi, que ele levantou (' $\epsilon \gamma \epsilon \hat{\imath} \rho \omega)$, de cuja descendência levantou (idem) a Jesus para Salvador, ao qual, tendo-o os homens crucificado e sepultado, Deus ressuscitou (ibid) dos mortos. Paulo termina fazendo uma síntese do seu argumento, começando com estas palavras: "E nós vos anunciamos que a promessa que foi feita aos pais,

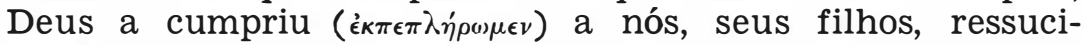

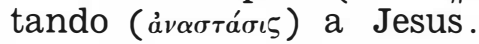

Duas coisas transparecem dessa leitura. De um lado, nota-se que Paulo atribui à ação direta de Deus os acontecimentos da história de Israel; por outro, percebe-se que, na estrutura do seu discurso, ele seguiu simplesmente a tradição da Lei e dos Profetas, cujos textos cita para apoiar a sua interpretação ${ }^{(31)}$.

O Prof. G. Ernest Wright, num dos seus melhores livros - God Who Acts - cujo subtítulo define a obra Biblical Theology as recital - escreve, a propósito da mesma passagem acima citada, que os eventos a que o apóstolo São Paulo se refere correspondem àqueles que os israelitas compreendiam como atos de Deus ${ }^{(32)}$.

Para G. von Rad, também, a revelação de Deus dá-se através de palavras e de atos divinos que se fixam historica-

(31) [39]; [42].

(32) $[113 \mid$ p. 76. 
mente como acontecimentos de natureza particular." (33) Do mesmo modo, Edmond Jacob( ${ }^{(34)}$ afirma que, na revelação divina dos livros canônicos dos hebreus, inutilmente se buscarão dogmas ou proposições metafísicas; em seu lugar, encontrar-se-ão eventos carregados de história e de sentido ${ }^{(35)}$.

Teologia do Velho Testamento. O substrato judáico.

a) O cerimonial.

Os dias e festas sagrados são um fenômeno universal em todas as religiões, desde as mais "primitivas" até às de mais elaborada estrutura social e mais racionalizado sistema doutrinário. A criteriosa análise fenomenológica dessa importante esfera da história das religiões, realizada pelos mais notáveis pesquisadores, desde Frazer e Max Müller até van der Leeuw e Mircea Eliade, leva-nos à conclusão de que as festividades de que a Bíblia dá notícia, tanto do Velho como do Novo Testamento, têm um conteúdo e significado sui generis .

As periódicas festividades religiosas em Israel obedeciam a um ritual de que parece ser modelo a estrutura do livro de Deuteronômio, cujos primeiros onze capítulos são uma parênese e uma exposição dos acontecimentos do monte Sinai ${ }^{(36)}$. Por meio desses atos litúrgicos, a revelação sinaítica conservava toda a sua atualidade ao longo do tempo, repetindo-se em cada sucessiva geração, e tornando-se contemporânea de todas elas ${ }^{(37)}$. O acontecimento transformava-se "num mito de um drama litúrgico no qual os grandes fatos da salvação se tornavam "acontecimentos" que o povo vivia como história contemporânea" ${ }^{38)}$.

Apesar da tentativa de "exegese histórica" dos mitos helênicos feitas por alguns intérpretes de Homero, sobretudo

(33) [82] vol. II p. 357.

(34) [58] pp. 150ss.

(35) Veja-se, por exemplo, Dt 26,5ss e o prefácio ao Decálogo (Ex 20,1-2; Dt $5,1-6)$.

(36) $[85-\mathrm{A}\rceil$ p. $207 \mathrm{ss}$.

(37) [82] vol. I p. 194.

(38) Weiser, A., Die Psalmen, Göttingen, 1950,p. 18. Apud [85-A] p. 208. 
por Palaiphatos, com apoio nos estudos iniciados por seu mestre Aristóteles, nenhuma semelhança podemos observar entre a natureza das festas olímpicas e outras solenidades dos diversos cultos de mistérios dos povos helênicos ${ }^{(39)}$ e as características das divisões do tempo sagrado dos judeus. $\mathrm{O}$ mesmo se pode dizer em relação à vida religiosa do povo romano comparada com o judaismo bíblico. São, no meu modo de sentir, convincentes os argumentos de George Dumézil em defesa da tese de que, ao se instalarem no Lácio, os homens que criaram Roma traziam consigo "uma herança religiosa considerável" que entretanto não se pode explicar por sua história. Mas - diz Dumézil - "a partir daí, tudo é história" (40). Contudo, nada há, nessa relação entre a religião e a história desse povo extraordinário que possa comparar-se com a religião e a história do povo hebreu, que se identificaram na mensagem dos profetas e dos apóstolos. Como judiciosamente observa H. H. Rowley, da Universidade de Manchester, mesmo a própria Lei que, no canon, ocupa lugar distinto do dos livros históricos, não era fruto da especulação dos seus sábios e legisladores, mas resultado da experiência histórica do próprio povo. Na realidade, nota o Dr. Rowley, o caráter histórico está presente nas três divisões da Bíblia hebráica ${ }^{(41)}$.

Em Israel, mesmo quando, no nome e no ritual das festas, se mantinham as marcas de suas raízes semíticas do período arcáico, ligadas a influências dos povos vizinhos, de sentido agrícola e pastoril, o seu mais profundo significado era, entretanto, a recordação dos atos de Deus na sua história. Igualmente, o dia sagrado por excelência - o shabbath - deve ser guardado, segundo o Deuteronômio, porque o povo precisava lembrar-se de que tinha sido escravo no Egito e Deus o tinha tirado de lá "com mão forte e braço estendido" (Dt 5,15).

A Páscoa (14-15 de Nizan) comemorava a libertação do povo da opressão de Faraó (Ex 12). A Festa do Pentecostes ou das Primícias $(\mathrm{Nm} \mathrm{28,26)}$ foi associada pelo judaismo

(39) Ver Buffière. Felix, Les Mythes d'Homère et la Pensée Grecque, Paris, 1956, pp. 228 ss.; G. van der Leeuw, Fenomenologia de la Religion, $\S \S 34,52,56,64$ e 85 . Sobre a ausência de sentido ou de mensagem "históricos "nas festars religiosas dos povos helenos, ver. P. Maxime Schüll, Essai sur la formation de la pensée grecque, passim.

(40) La Religion Romaine Archä̈que, Paris, 1966, p. 141.

(41) $[87-\mathrm{A}]$. 
posterior com a dádiva de Lei de Deus. A Festa dos Tabernáculos lembrava os 40 anos de existência nomádica pelo deserto, a caminho de Canaã. William R. Irwin, da Universidade de Chicago, insiste em que "the Hebrew cultic drama portrayed not alone the cosmic triumph, but also the 'great works of the Lord' in Egypt and in the wilderness and in Canaan", e lembra, a propósito, os "lenghty historical surveys" dos Salmos $78,105,106$, etc. ${ }^{(42)}$.

As outras festas menores comemoravam igualmente fatos da história sagrada do povo judeu. Assim a Hannukkah lembra a rededicação do templo por Judas Macabeu. O registro relativo à celebração do ano do jubileu, que se dedica ao repouso sabático da terra após "sete semanas de anos" $(\operatorname{Lv} 25,8)$, termina com estas palavras: “...porque os filhos de Israel são meus servos pois eu os tirei da terra do Egito" $(\operatorname{Lv} 25,55)$. E assim por diante. O mesmio se verifica no tocante ao Decálogo, cujo prefácio, incluído no $1 .^{\circ}$ mandamento, reza: "Eu sou o Senhor teu Deus que te tirei da terra do Egito: Não terás outros deuses diante de mim." (Ex 20,2; Dt 5,6). ${ }^{(43)}$

\section{b) A língua hebráica}

Em razão das suas peculiaridades, a língua dos profetas se prestava, como nenhuma outra, à comunicação da sua mensagem. No hebráico, o verbo é mais importante do que o substantivo, e, por vezes, este mesmo tem de ser traduzido por uma forma verbal. Assim, por exemplo, ocorre com DBR (dabar) palavra, que tem um duplo sentido básico. Pode referir-se ao significado profundo da palavra, à sua realidade anterior ou pode referir-se ao evento dinâmico no qual aquele sentido interior se torna manifesto. Com muita inteligência, receberam e traduziram esse termo os que se encarregaram da Septuaginta, e o mesmo se pode dizer no caso do Novo Testamento, nas citações das Escrituras, pois nesses dois monumentos da literatura religiosa, dabar (no singular) se traduz por logos (palavra), mas, no plural (debarim) por egéneto (aconteceu), aoristo de gínomai. Assim o que está no hebráico literalmente: "A palavra do Senhor veio

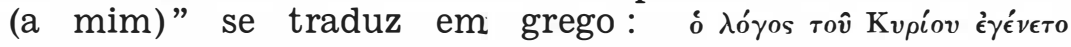

(42) [57] pp. 174ss.

(43) Ver sobre este tema, [76-A] vols. III e IV, passim; [73] pp. 139-143. 
$\pi$ pós $\mu \epsilon \ldots$, isto é, a palavra do Senhor aconteceu. ${ }^{(44)} \mathrm{O} \mathrm{Dr}$. Torrance lembra que palavra, no segundo sentido citado, equivale a "história", como no latim res gestae (45)

O grego do Novo Testamento, a кoเví, é já uma língua muito diferente da dos diálogos de Platão e prestava-se muito melhor às intenções dos apóstolos e evangelistas. Mas estes não tiveram dúvida em aumentar ainda mais essa diferença, modificando o sentido das palavras, empregando-as como veículo de conteúdo hebráico. Isto se torna particularmente significativo no emprego do vocábulo logos, principalmente em São João. No começo do seu esplêndido comentário ao Quarto Evangelho, C. H. Dodd lembra aqueles versos do Fausto de Goethe onde o herói da tragédia luta com o texto grego do Evangelho de São João: No princípio era o Verbo, acabando por escolher o termo ação. "No princípio era a Ação". Não sei se Goethe teria em mente o relacionamento deste começo do Evangelho com o começo da Bíblia hebráica onde a Palavra de Deus cria o universo: "E disse Deus: Haja luz...", etc. Ou se pensou numa exegese do texto inicial de João combinado com o verso 14: "E o Verbo se fez carne ( $\left.\operatorname{sa\rho \xi \xi \epsilon } \boldsymbol{\epsilon}^{\prime} \epsilon \in \epsilon \tau\right)$. "A Palavra aconteceu...".

Mas foi, segundo o evangelista, o que realmente houve. A Palavra de Deus encarnou e irrompeu na história humana. No Credo, a frase sob o poder de Pôncio Pilatos identifica o momento preciso.

\section{c) Dialética e teologia}

No seu livro sobre Paulo, já citado neste trabalho, diz Martin Dibelius que o apóstolo nenhum conflito via na coexistência do profético testemunho direto com a dialética teológica. Tratando da questão do batismo e da eucaristia nos escritos do apóstolo dos gentios, diz Dibelius que Paulo, partindo do Deus da história, em quem criam os judeus, relacionou a vida religiosa do cristão com o ato histórico de Deus operando a salvação em Cristo, e, assim, impediu que a piedade degenerasse em misticismo ou se reduzisse a meros atos formais de culto litúrgico. ${ }^{(46)}$

(44) Ver sobre essa questão [5-A] bem como [11] que o primeiro citało critica.

(45) $\lceil 103-\mathrm{A}\rceil$.

(46) [37] p. 123. 
Dom Miguel de Unamuno, que tantas vezes na sua extensa obra aludiu ao apóstolo e o citou nas suas cartas, embora nunca tivesse feito qualquer comparação entre a estrutura formal da argumentação de Paulo e a dos estóicos, todavia, não deixou de observar, com muita argúcia, em La Agonia del Cristianismo, que a dialética "terrível" e "agônica" do apóstolo das gentes não se compadecia com qualquer lógica baseada em conceitos (47). Doutra feita, indagou se era a extensão que fazia a diferença entre um artigo e um ensaio, ou entre este e um sistema. "Que diferença há - escreve D. Miguel - entre uma epístola de São Paulo a póstolo, que é um artigo de periódico (grifo meu), e a Suma de Santo Tomás, que é um sistema?" (48). Um artigo de periódico! No sentido em que Unamuno o toma, o artigo de jornal reflete o caráter temporal, histórico, da temática da existência, do diário, do journal. A Suma se constrói toda sobre conceitos e definições.

Ao finalizar o seu interessante e bem feito livro sobre o gênio grego na religião, escrevem Gernet e Boulanger que o Cristianismo se aproveitou de toda a evolução religiosa do helenismo sem contudo vir a ser o resultado dessa evolução. Graças ao elevado valor moral e espiritual da religião cristã, ao ardor com que seus apóstolos a difundiram, e também graças à invencível intransigência destes, o Cristianismo se converteu rapidamente na religião do mundo greco-romano. ${ }^{(49)}$

Eu creio, porém, que, além dos fatores enumerados por esses autores, seria preciso acrescentar o que Marcel Simon com tanta clareza e exatidão escreveu sobre o fato da ressurreição de Cristo, sobre cuja realidade não compete ao historiador tratar, mas que "Tudo o que o historiador pode e deve consignar e afirmar é que qualquer coisa se passou sem a qual todo o desenvolvimento ulterior do Cristianismo teria sido impossível" (49-A). E, além disso, não se poderia deixar de mencionar a forma utilizada pelo maior dos missionários do primeiro século na apresentação da mensagem. É verdade que o A. afirma que São Paulo, "o maior dos dou-

(47) La Agonia del Cristianismo, O.C. XVI p. 519.

(48) En torno a la lengua española, O.C. VI p. 671.

(49) [14] p. 354 (da ed. mexicana. FCE).

(49-A) Apud Jean Remy Palanque, Empirc Universel de Rome, na Histoire Unizerselle (Pleiade), direção de R. Grousset e E. G. Léonard, vol I p. 1017. 
tores do Cristianismo primitivo", definiu a religião de Cristo para o mundo helênico (p. 353), mas seria necessário esclarecer de que definição se trata. Ela certamente não se

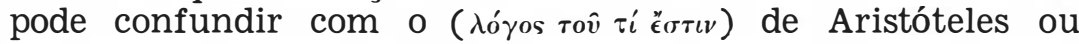
com alguma espécie de oratio naturam rei aut termini significationem exponens que iria encher uma boa parte do tempo dos doutores da escolástica ${ }^{(50)}$.

Kant, no Le Conflit des Facultées, sublinha esse mesmo aspecto da argumentação do apóstolo. Ao referir-se ao capítulo $15 \mathrm{da} 1 .^{\mathrm{a}}$ carta aos Coríntios, em que Paulo apresenta uma série de provas da ressurreição de Jesus Cristo, Kant diz que, em última análise, o que realmente levou o apóstolo a aceitar o fato da ressurreição de Cristo, foi a fé. Sem ela, dificilmente teria ele aceitado a realidade do acontecimento. No entanto, diz o filósofo da Crítica da Razão Pura que a argumentação de Paulo se funda no fato "histórico": “...lui a fait accepter la croyance historique à une chose publiquement connue qu'il admit de bonne foi comme vrai." (51)

A própria palavra pela qual é conhecida no Novo Testamento a mensagem de Cristo - Evangelho (em grego, boas novas) - tem um tom jornalístico, de noticiário. Mas um noticiário que faz presente o passado e antecipa o futuro. A escatologia é um dos capítulos mais importantes da teologia do Novo Testamento. O presente era o caminho do cristão em trânsito - semper viator.

Paulo não era um filósofo que reunia discípulos em torno de si para a discussão de questões relativas à teoria do conhecimento, mas um evangelista, um noticiarista da parte de Deus, que anunciava a vinda do Reino de Deus, o qual nos leva a "condenser le passé et le futur dans un temps nouveaux, où il nous faut simultanément être attentif au Jésus de Nazareth et au Seigneur glorieux", como diz Roger Mehl em La condition du Philosophe Chrétien ${ }^{(52)}$.

(50) Encontro, num tratado de lógica norte-americano - Lionel Ruby, Logic - An Introduction, Chicago, 1960 - entre os exercícios em torno do problema das definições, um sobre a que São Paulo teria oferecido da fé, em $\mathrm{Hb}$ 11,1: "A fé é o firme fundamento das coisas que se esperam, e a prova das coisas que se não vêem". Acontece, porém, que, com certeza, não foi São Paulo quem escreveu a epístola aos Hebreus.... Atribui-se a Orígenes a opinião de que só o Espírito Santo sabe quem era o autor daquele livro do Novo Testamento.

(51) Na tradução de J. Gibelin. Vrin, 1955, pp. 43-44.

(52) Roger Mehl, La Condition du Philosophe Chrétien. 
"A fé está ligada a uma duração temporal — diz o mesmo autor - a qual tem sua tensão própria; ligada a uma história que não se pode esquecer (ibid.) Mas essa mensagem veio a concentrar-se numa doutrina, isto é, num dogma, não no sentido moderno da palavra - um conjunto ou sistema de verdades inertes - mas, como bem se expressou ainda o mesmo autor (p. 115), a expressão de uma ordem, de uma vontade, inseparável do próprio ato do querer. O dogma é, antes de tudo, um decreto. É a vontade de Deus para nós, a exigência divina a respeito da pessoa, a exigência que o homem não pode reconhecer a não ser que se engage ao serviço da mesma exigência. (Ibid. p. 114).

A Revelação é, pois, esse dogma, esse decreto que não se pode compreender se o abstraimos do ato da Revelação, a qual não é um discurso sobre Deus, mas sim o próprio ato de Deus.

\section{Conclusão:}

Ao chegar ao fim deste estudo, permita-se-me uma referência pessoal. Jamais poderei esquecer a visita que, em companhia de Júlio Ferreira, Roberto Rios e Valdo Galland, fiz a Karl Barth, na tranqüilidade do seu escritório, em sua casa, em Basiléia, numa nevosa manhã de domingo, em Janeiro de 1952. Era a primeira visita, disse-nos ele, que recebia de latino-americanos. Cada um de nós levava engatilhada uma série de perguntas sobre questões teológicas, naturalmente. Um dos meus desejos era ouvir a Barth falar, de viva voz, sobre a Bíblia e a revelação, tema por ele tantas vezes tratado na Dogmática e nos Comentários exegéticos. Voltou-se para a estante que estava atrás de si, repleta de clássicos gregos e latinos, padres da Igreja, filósofos e teólogos, poetas e romancistas de muitas nacionalidades. A Bíblia - disse-nos - entre livros como aqueles, simplesmente, era como um deles, um livro humano. A Bíblia e a Revelação divina são duas coisas distintas. Elas coincidem somente quando a Revelação se dá, como um acontecimento no espírito do leitor das Escrituras, enquanto a leitura se processa. Quando a mesma Palavra de Deus que caiu na alma do escritor bíblico ecôa, ela mesma, na alma daquele que o lê, e Deus fala aqui e agora ao coração do homem tão realmente como falou na antiguidade, então, dá-se $o$ acontecimento da Palavra de Deus. 
Hoje, retomo os volumes da sua monumental Dogmática, o seu revolucionário comentário da Epístola de Paulo aos Romanos, a sua brilhante análise da história do pensamento protestante - Kant, Rousseau, Leibniz, Hegel, etc. e vou encontrando por toda parte aquela idéia caindo da sua pena. No comentário exegético, ou na simples leitura da Bíblia, vive com o texto até que este desaparece e ele se defronta com a própria palavra de Deus. É o segredo do seu método exegético. A Palavra de Deus é ato de Deus, é acontecimento, é criadora de história ${ }^{(53)}$. "Os profetas anunciam e os apóstolos pregam a Cristo, não como cronistas, mas como testemunhas". Não falam somente de Cristo, mas $\mathrm{em}$ Cristo. Não porque tivessem conhecido a Cristo como se pode conhecer a Platão, mas porque "aprouve a Deus revelar seu Filho nele" $(\mathrm{Gl} 1,15,16)$. ${ }^{(54)}$. O encontro com Cristo é um "acontecimento ético": é um encontro de Deus concreto com o homem concreto em Jesus Cristo. Tal entrevista não se dá no vazio, mas num quadro determinado pelo caráter inconfundível dos dois parceiros que se defrontam. Como conseqüência a própria ética não se acha em face de um dado geral impossível de exprimir no plano particular, mas pode e deve tornar-se ética especial. ${ }^{(55)}$

A reconciliação entre Deus e o homem é uma história. Quem pretender conhecê-la, deve conhecê-la como tal. Quem quiser referir-se a ela, deve contá-la como história. Quem quer que pretenda conceber a reconciliação como verdade supra-histórica ou a-histórica, jamais a compreenderá. Ela é certamente uma verdade, mas uma verdade que se passa num acontecimento histórico e na história se manifesta ${ }^{(56)}$. Os dois acontecimentos fundamentais interdependentes que transformaram a história humana foram a morte e a ressurreição de Jesus Cristo ${ }^{(57)}$. Na morte de Cristo, Deus reencontra o homem e o homem a Deus. Na ressurreição de Cristo, aquele duplo acontecimento é anunciado, e, pelo Espírito Santo agindo em nós, torna-se um acontecimento presente incessantemente para nós ${ }^{(58)}$.

A comunidade das testemunhas desses acontecimentos,

(53) [6] vol. T. p. 139.

(54) id. p. 144.

(55) id. vol. XV p. 26.

(56) id. XVII p. 164.

(57) ibid. p. 328.

(58) id. p. 165. 
isto é, a Igreja, tem também a sua história, é também acontecimento. Está de tal modo presente na história do mundo que, sem ela, esta nenhum sentido teria ${ }^{(59)}$.

Interessante é o que diz o grande teólogo sobre o estoicismo nos dias de São Paulo. Se se quiser - escreve ele, ${ }^{(60)}$ compreender o keryssein neo-testamentário, é preciso, pelo menos, lembrar a presença do fenômeno estóico na mesma época. Os estóicos tinham também uma mensagem divina, mas transmitiam-na com palavras de sabedoria humana. É a eles que se refere Paulo aos Coríntios e aos Filipenses quando diz que não lhes pregou com palavras de sabedoria humana. A mensagem apostólica era na verdade uma narrativa, uma história. Por mais singelos que fossem, e por mais chocantes para a mentalidade helenística, ele dizia que deles não se envergonhava, porque eram o poder de Deus $(\mathrm{Rm} 1,16)$. Jesus Cristo, como pessoa, como entidade histórica, era "sabedoria e poder de Deus" (1 Co 1,24).

Num belo estudo sobre a dinâmica da tradução, Jules Laurence Moreau ${ }^{(61)}$ dedica um capítulo à questão da inadequabilidade dos diversos tipos de lógica existentes, desde a clássica aristotélica até o positivismo do círculo de Viena e o Tractatus Logico-Philosophicus, à análise das questões relativas à teologia bíblica, que se coloca essencialmente no nível da história, inadequabilidade essa aparentemente reconhecida, quanto ao último caso, pelo próprio Wittgenstein, que admite que o seu sistema se presta às questões científicas e não aos problemas da vida, que não teriam sido sequer tocados por ele (o seu sistema), mesmo quando todas as questões científicas tivessem sido resolvidas ${ }^{(62)}$.

Mostra Moreau que, no plano metalingüístico, o hebráico revela um caráter de "event-counsciousness" que é fundamental para a lógica da história". E essa deve ser a que norteará os pesquisadores da história social e religiosa dos hebreus e dos cristãos dos tempos bíblicos.

Os leitores de Marc Bloch estarão lembrados de uma aguda observação sua de que "uma iluminação interior bastará ao puro deista para crer em Deus. Mas não para crer

(59) id. vol. XIX p.

(60) id. vol. XX p. 213.

(61) [71] pp. 132-139.

(62) [112] 6.52 . 
no Deus dos cristãos". "Porque o Cristianismo" - escreve ele - "já o tenho dito mais de uma vez, é por essência uma religião histórica. Quero dizer com isso que é uma religião cujos dogmas primordiais repousam sobre acontecimentos. Lêde de novo o vosso Credo: Creio em Jesus Cristo... que foi crucificado sob Pôncio Pilatos... e ressurgiu dos mortos ao terceiro dia" ${ }^{(63)}$.

Certo. Mas penso que o grande mestre dos Annales se equivocou ao escrever esta frase com que termina esse parágrafo acima citado: "Aí estão os fundamentos do começo da fé". Porque, a rigor, para o cristão, para Paulo, por exemplo, o começo estava já nos acontecimentos narrados no Velho Testamento, sem os quais, na realidade, a vida, a morte e a ressurreição de Jesus Cristo ficariam sem sentido. Porque o milagre espantoso da ressurreição de Jesus não foi em si mesmo o fundamento da fé daqueles que são chamados "filhos de Abraão". Ela foi, por assim dizer, com a descida do Espírito Santo no Pentecostes, o último dos acontecimentos da história da salvação que constituiram a base dos demais artigos do mesmo Credo: a Igreja, a comunhão dos santos, a remissão dos pecados, a ressurreição do corpo, a vida eterna. Blaise Pascal sintetizou isso nas palavras iniciais do pequeno manuscrito que os que prepararam o seu corpo para a sepultura encontraram preso à sua roupa, junto ao coração: "Deus de Abraão, Deus de Isaque, Deus de Jacó, não o dos filósofos e dos sábios. Deus de Jesus Cristo" (64) .

"Não podemos deixar-nos seduzir, diz o Catecismo Holandês, pelos santinhos e gravuras da 'História Sagrada' do séc. XIX, com as nuvens, os raios, os triângulos no céu! E no labutar e no falar de homens que Deus nos deu a sua Revelação única" (65).

$\mathrm{E}$ assim, mediante o testemunho moderno, não apenas dos teólogos, mas dos exegetas, como quer Paul Ricoeur,

\footnotetext{
(63) [8] D. 6.

Sobre a questão da "historicidade" da ressurreição de Cristo, de que Paulo trata em 1 Co 15,1-8, ver (49-A) loc. cit.; Karl Barth, Credo, p. 125 ss; O. Cullmam, K. Barth, et all., Comprendre Bultmann, Paris, 1970, passim; sobre toda a questão do problema histórico ou mítico, ver R. Mehl, Traité de Sociologie du Protestantisme, Neuchatel, pp. 76-97.

(64) Morris Bishop, Pascal, The Life of a Genius, New York, 1936, pp. 172-173. A conhecida edição dos Opuscules e dos Pensées, de Léon Brunschvicg, insere o texto nos Opúsculos sob o n. ${ }^{\circ} 13$ da 2. ${ }^{a}$ parte (pp. 142-143).

(65) Catecismo Holandês, p. 65.
} 
amparados no rigor da pesquisa científica aplicada à Bíblia, do Velho como do Novo Testamento, podemos não somente perceber qual a forma de estrutura lógica preferida pelo apóstolo Paulo na sua sólida argumentação, como também as razões profundas por que assim procedeu. A lógica de Aristóteles como a dos estóicos tinham a sua base metafísica. O Evangelho de Paulo baseava-se numa concepção teológicoexegética da História vista à luz das narrativas dos historioógrafos do Velho Testamento e da hermenêutica dessas narrativas trabalhada pelos profetas hebreus.

Essa base, segundo entendo, justifica plenamente a opção feita pelo apóstolo dos gentios do formalismo lógico de Crísipo.

\section{BIBLIOGRAFIA}

[1] Albright. William Foxwell, From the Stone Age to Christianity, Baltimore, 1940.

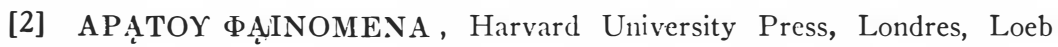
Classical Library, 1960.

[3] Ardt. William F.; \& Gingrich. F. Wilbur, A Greek-English Lexicon of the New Testament and other Early Christian Literature, Chicago, 1957.

[4] Arnold. E. Vernon, Roman Stoicism, Londres, 1911.

[5] Bailbé. Jacques, Agrippa d'Aubigné et le stoïcisme. Bulletin de l'Association Guillaume Budé. 4e Série, n. ${ }^{\circ} 2.1965$.

[5-A] Barr. James, The Semantics of Biblical Language.

[6] Barth. Karl, Dogmatique (trad. francesa), Genève, 1953-1974. 28 volumes.

[7] Barth. Karl, The Epistle to the Romans, Oxford University Press, Londres, 1950.

[7-A] Blanché. R., La Logique et son Histoire, Paris, 1970.

[8] Bloch. Marc, Apologie pour l'Histoire ou Métier d'Historien, Paris, 1952. (Cahiers des Annales. N. ${ }^{\circ} 3$ ).

[9] Boschenski. J. M., Ancient Formal Logic.

[9-A] Boschenski. J. M., Historia de la Lógica Formal, Madrid, 1966. Trad. esp. de M. B. Lozano.

[10] Boschenski. J. M., La Lógica de la Religion, Buenos Aires, 1967.

[11] Thorlief, Boman. Hebrew Thought compared with Greek, Londres, 1960. 
[12] Bonsirven. Joseph, L'Evangile de Paul, Paris, 1948.

[13] Borgeaud. Willy, et Roussel. Michel, Sur un text des Contraditions Stoïciennes de Plutarque. In Revue des Etudes Grecques, T. LXXXII Jan.--Juin, 1969, Paris.

[14] Boulanger. Gernet et, La génie grecque dans la religion.

[15] Bréhier. Emile, La Théorie des Incorporels dans l'Ancien Stö̈cisme, 3. ${ }^{\mathrm{a}}$ ed., Paris, 1962.

[16] Bréhier. Émile, La Philosoplie du Moyen Age, Paris, 1949.

[17] Bréhier. Émile, Etudes de Philosophie Antique, PUF, 1955.

[18] Bréhier. Émile, Chrysippe et l'Ancien Stoïcisme. Paris, 1951.

[19] Brun. Jean, Les Stoïciens. Textes Choisis. Paris, 4. a ed., 1968.

[20] Brunner. Emil, The Divine-Human Encounter, Londres, 1944.

[21] Brunot. Amédée, Le Génie Litteraire de Saint Panl, Paris, 1955.

[22] Bultmann. Rudolf, Le Christianisme Primitif dans le cadre des religions antiques. Paris, 1950.

[23] Bultmann. Rudolf, Existence and Faith, Londres, 1960.

[24] Bultmann. Rudolf, Theology of the Nerv Testament. Londres, 1952.

[25] Cadbury. Henry J., The Book of Acts in History, Londres, 1955.

[26] Cary. M., The Geographic Background of Greek and Roman History, Oxford, 1949.

[27] Chalus. Paul, L'Homme et la Religion. Recherches sur les Sources Psychologiques des Croyences. Paris, 1963.

[28] Charles. R. H., Religious Development between the Old and the New Testaments. Londres, 1948.

[29] Chevalier. Jacques, Histoire de la Pensée, Paris, 1955.

[30] Chrevallier. R., Le Milien stö̈cien à Rome au ler siècle ap. J.-C.. L'Âge herö̈que du Stoïcisme roman. In Bulletin de l'Association Guillaume Budé. n. 4, 1960.

[31] Chiodi. Pietro, La dialéctica hegeliana in Abbagnano. Nicola, et all, La Evolución de la Dialectica, Barcelona, 1971.

[32] Cohen. Gerson D., La Epoca Talmúdica, Buenos Aires, 1965.

[33] Colardean. Th., Etudes sur Epictète (Thèse), Paris, 1903.

[34] Croiset. A. M., Histoire de la Littérature Grecque, 1928.

[35] Crubellier. Maurice, L'événement en Histoire Sociale, in L'Histoire Sociale. Sources et Méthodes. Colloque de l'École Normale Supérieure de Saint-Cloud (mai, 1965). Paris, 1967.

[36] Deissmann. Adolf, Paul. A study in Social and religious History. Londres, 1926.

[37] Dibelius. Martin, Paul. Londres, 1953.

[38] Dilthey. W., Le Monde de l'Esprit. Paris, s/d.

[39] Dodd. Charles Harold, Conformément aux Ecritures, Paris, 1968. L'infrastructure de la Théologie du Nouveau Testament.

[40] Dodd. C. H., The Apostolic Preaching and its developments. New York, 1954. 
[41] Dodd. C. H., Romans, New York, 1932.

[42] Ellis. E. Earle, Paul's Use of the Old Testament, Grand Rapids, 195.7

[43] Festugière. O. P. A. J., L'Idéal Religieux des Grecs et l'Evangile.

[44] Filson. Floy V., The New Testament against its environment, Londres, 1950.

[45] Funk. Robert W., Language, Hermeneutic, and Word of God. The problem of language in the New Testament and Contemporary Theology. New York, 1966.

[46] Gilson. Etienne, La Philosophie au Moyen Age. Paris. 1952.

[47] Glover. T. R., Paul of Tarsus, Londres, 1925.

[48] Goldschmidt. Victor, Le Système stö̈cien et l'idée de temps. Paris, 1953.

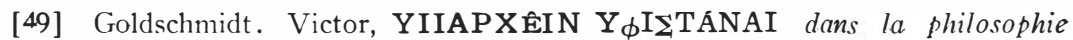
stoïcienne, in Revue des Etudes Grecques, Tome LXXXV - Jui-Dec. 1972.

[50] Granger. Gilles Gaston, Lógica e Filosofia das Ciências. S. Paulo, 1955.

[51] Grant. F. C., The Economic Background of the New Testament in The Background of the New Testament. Studies in honour of C. H. Dodd, Cambridge Univ. Press, 1964 (pp. 96-114).

[52] Grant. F. C., Roman Hellenism and the New Testament. Edinburg. 1962.

[53] Grilli. Alberto, Il problema della vita contemplativa nel mondo grecoromano, Milano, 1953.

[54] Gusdorf. Georges, Introduction aux Sciences Humaines. Paris, 1960.

[55] Hadot. Pierre, La Notion de "Cas" dans la logique stoïcienne in Le Langage. Actes du XIII.e Congrès des Sociétés de Philosophie de Langue Française. Genève, Agosto, 1966.

[56] Haury. A., Les deux voies du Stoïcisme Romain, Bulletin de l'Association G. Budé, 4.a série, n. 3. 1963.

[56-A] Holtzener. Mgr. Joseph, Paul de Tarse, Paris, 1950.

[57] Irwin. William A., The Old Testament: Keystone of Human Culture. Londres, 1959.

[58] Jacob. Edmond, Théologie de l'Ancien Testament, Neuchâtel, 1955.

[59] Kimpel. Ben F., Language and Religion. A Semantic preface to a philosophy of religion. N. York. 1957.

[60] Kittel. Gerhard (edit.), Theological Dictionary of the New Testament, Grand Rapids, 1964.

[61] Kotarbinski. Tadeusz, Leçons sur l'Histoire de la Logique, Paris, 1964.

[62] Kraemer. Hendrik, La Foi Chrétienne et les Religions non chrétiennes. Neuchâtel, 1956.

[63] Kraemer. H., et all., On the meaning of History. Papers of the Ecumenical Institute. N. V. Génève, 1950.

[64] Lampe G. H., e Woolcombe. K. J., Essays on Typology, Londres, 1957. 
[65] Landgraf. Arthur Michael, Introduccion a la Historia de la Literatura Teologica de la Escolastica Incipiente. Barcelona, 1956.

[66] Lestringant. Pierre, Essai sur l'unité de la Révélation Biblique. Paris, 1942.

[67] Leuba. Jean-Louis, L'Institution et l'évènement. Les deux modes de l'ouvre de Dieu selon le Nouveau Testament. Neuchâtel, 1950.

[68] Malingry. Anne-Marie, "Philosophia". Etude d'un groupe de mots dans la littérature grecques des présocratiques au IV.e siècle aprè J.-C., Paris, 1961.

[69] Marcus. Ralph, La Epoca Helenistica. Buenos Aires, 1965.

[70] Mates. Benson, Stoic Logic, Berkeley, 1961.

[71] Moreau. Jules Laurence, Language and Religious Language. A study in dynamics in translation. Philadelphia. 1961.

[72] Moulton. W. F., e Geden. A. S., A Concordance to the Greek Testament. 3.a ed. Edinburg. 1950.

[73] Noth. Martin, Histoire d'Israel, Paris, 1954.

[74] Nygren. A., Agape and Eros, Philadelphia, 1953.

[75] Onoré, .., Les Formes littéraires de la pensée grecque, Paris, 1900.

[76] Padres Apostólicos. Edición bilingüe completa. BAC 1950.

[76-A] Pedersen. Joh., Israël, its life and culture, Copenhargue, 1926-1940.

[77] Perelman. Chaï, Le Champ de l'Argumentation, Bruxelas, 1970.

[78] Perelman. Chaïm, e Olbrechts-Tyteca. L., Traité de l'Argumentation, Paris, 1958.

[79] Pfeiffer. Robert H., History of Neze Testament Times, New York, 1969.

[80] Puech. A., Histoire de la Litterature grecque chrétienne. Paris, 1928.

[81] von Rad. Gerhard, Genesis. A commentary. Philadelphia, 1956.

[82] von Rad. G., Teologia do Antigo Testamento. São Paulo, 1973.

[83] Revue des Etudes Grecques. T. LXXXII. Jan.-Juin, 1969. Paris.

[83-A] Ricoeur. Paul, La Paternité: du fantasme au symbole in L'Analyse du langage Théologique. Le Nom de Dieu. Roma, 1969.

[84] Ricoeur. Paul, Les Incidents théologiques des recherches actuelles concernant le language. Institut d'Etudes Oecuméniques, s/.

[85] Rigaux, O. F. M. B., Saint Paul, Epitres aux Thessaloniciens; $\mathrm{Pa}$ ris, 1956.

[85-A] Ringgren. H., La Religion d'Israël.

[86] Rodier. Georges, Etudes de Philosophie Grecque, Paris, 1969.

[87] Rostovtzeff. M., The Social and Economic History of the Hellenistic World. Oxford, 1953.

[87-A] Rowley. H. H., The Growth of the Old Testament, Londres, 1964.

[88] Ruby. Lionel, Logic. An Introduction, Chicago, 1960.

[89] Sabatier. A., L'Apotre Paul, Paris, 1881.

[90] Schaff. Philip, History of the Christian Church. 
[91] Schlatter. Adolf, The Church in the New Testament Period, Londres, 1955.

[92] Scholz. Heinrich, Esquisse d'une histoire de la Logique, Paris, 1968.

[93] Schull. P. Maxime, Essai sur la formation de la pensée grecque. Paris, 1949.

[94] Schweitzer. Albert, Paul and his interpreters. A critical history. Londres, 1912.

[95] Scott. E. F., The Pastoral Epistles.

[96] Senarclens. Jacques de, Le Mystère de l'Histoire, Introduction à une conception christologique du devenir. Genève, 1949.

[97] Stacey. W. David, The Pauline viere of Man, in relation to its Judaic and Hellenistic Background. Londres, 1956.

[98] Stauffer. Ethelbert, New Testament Theology, 1955.

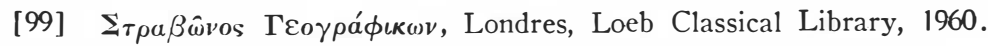

[100] Stucki. Pierre-André, Hermeneutique et Dialetique. Genève, 1970.

[101] Tcherikiver. Victor, Hellenistic Civilization and the Jews. Philadelphia, 1959.

[102] Thévenaz. Pierre, L'Homme et sa Raison, Neuchâtel, 19.52.

[103] Tillich. Paul, Systematic Theology, Chicago, 1953.

[103-A] Torrance. T. F., Royal Priesthood.

[104] Ueberweg. F., History of Philosophy. Tr. G. S. Morris. N. York, 1871.

[105] Vaux. R. de, O. P. Les Institutions de l'Ancien Testament, Paris, 1961.

[106] Verweyen. M., Historia de la Filosofia Medieval. Buenos Aires, 1957.

[107] Viano. Carlo Augusto, Dialectica estoica in Abbagnano. Nicola, et all, La evolucion de la dialetica. Barcelona, 1971.

[108] Virieux-Reymond. Antoinette, La Logique et l'Epistemologie des Stoiciens. Leurs rapports avec la logique d'Aristote, la logistique et la pensée contemporaines. Chambery, s/d.

[101] Varieux-Reymond. Antoinette, Quelques remarques à propos de la théorie du langage chez les stoïciens. in Le langage. Actes du XII Congrès des Sociétés de Philosophie de Langue Française. Genève, (Agosto de 1966).

[110] Zahn. Theodor, Introduction to the New Testament, Edinburg, 1909.

[111] Windelband. W., Historia de la Filosofia Antigua, Buenos Aires, 1955.

[112] Wittgenstein. Ludwig. Tractatus Logico-Philosophicus, trad. José Arthur Giannotti, U.S.P., 1968.

[113] Wright. G. Ernest, God who acts. Biblical Theology as recital. Londres, 1954. 